\title{
الاشتغالات المعرفية لنظرية اصالة الوجود في العرض المسرحي \\ (نظرية جوليان هلتون إنموذجاً)
}

ا.م.د.محمد كريم خلف كلية التربية

الفنية جامعة ميسان

\section{ملخص البحث}

تعد نظرية اصالة الوجود من النظريات المهمة في الفلسفة الإسلامية ، كونها

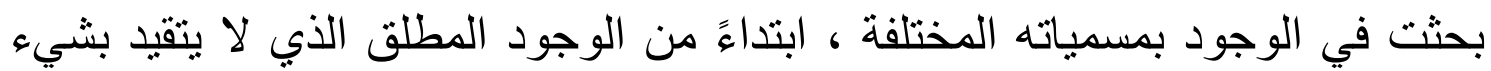

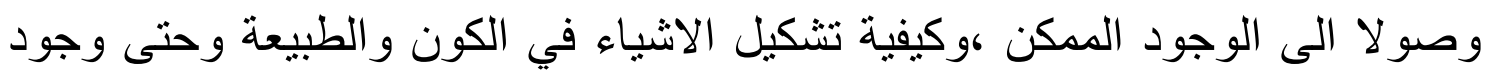

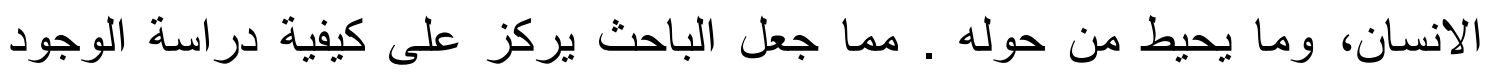

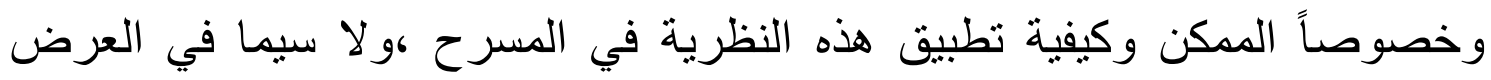

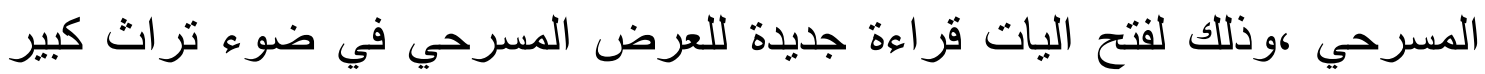

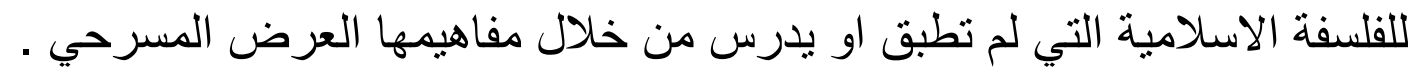

\section{Abstract}

The theory of authenticity presence of important theories in Islamic philosophy, being examined in the presence of various Bmsmyate, starting from the ubiquity which does not adhere to something down to the possible presence and how to shape things in the universe, nature and even the existence of man and the surrounding around him. Making the researcher focuses on how to study the existence and especially possible and how to apply this theory in the theater, especially the theater, so as to open new mechanisms read for viewing theater in the light of the great heritage of Islamic philosophy, which has not been applied or taught through concepts theater. 
ينطلق الخطاب المسرحي من تكوينات واطر مرجعية صيغت من خلال عناصر العرض المسرحي

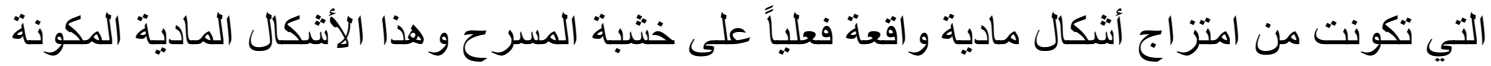

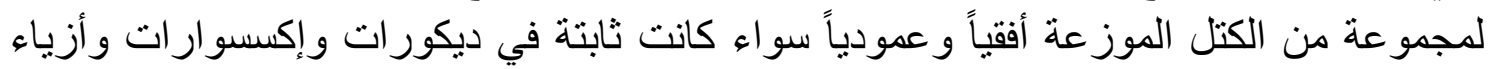

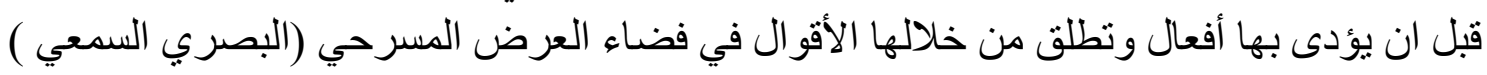
أو بعد ما يحولها الممثل بجسده المتحرك الى صود صور ذات ذات دلالات ومعاني مختلفة نشكل صور

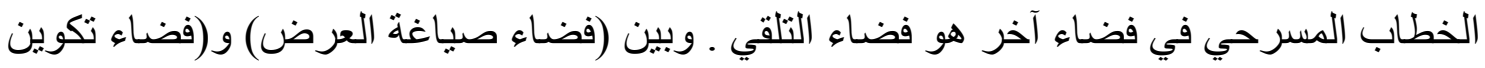

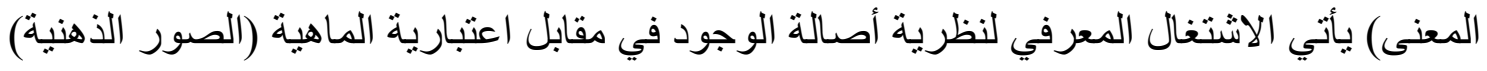
في فضاء التلقي مما يولد هذا الاشتغال اشكالية في انتاج المعنى ومدى ارتباطه في الوعي ونئه وتشكيل

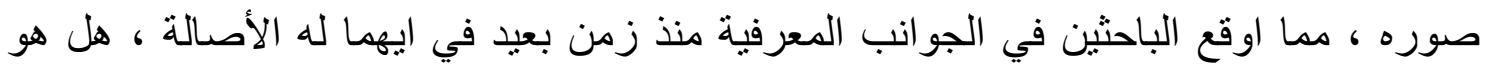

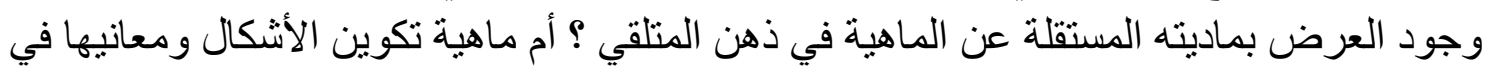

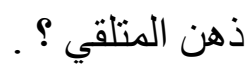

ان هذه الإشكالية (الأصالة والاعتبار) هي ليست وليدة الدراسات الأدبية والفنبة بل هي قديمة

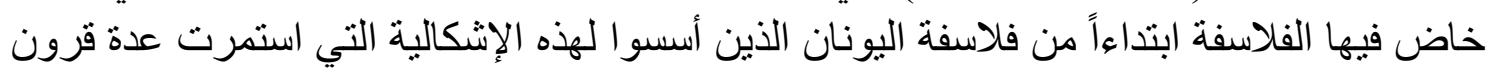

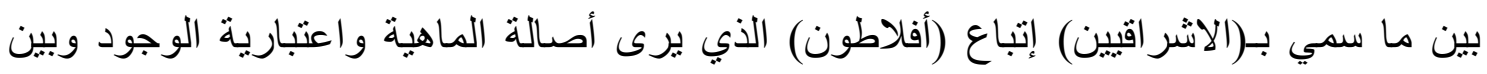

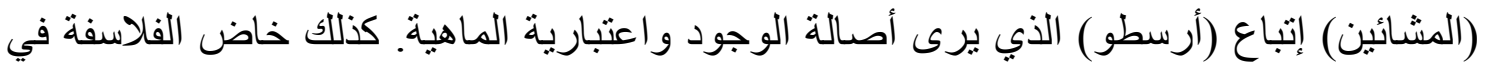

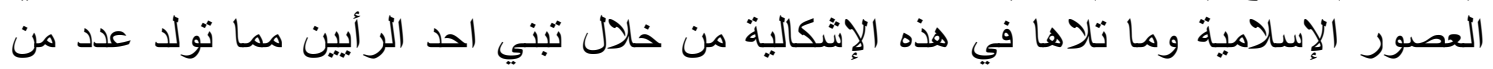
القراءات الفلسفية في ( الأصالة و الاعتبار) .

ان الخوض في هذه الإشكالية يحتاج للحفر في مفاهيم جديدة تنعكس ايجاباً على انتاج تصورات

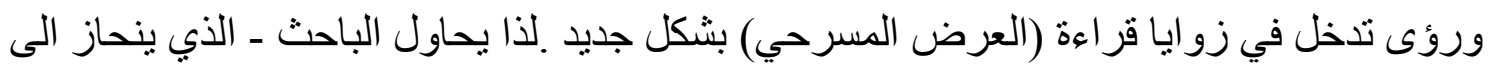

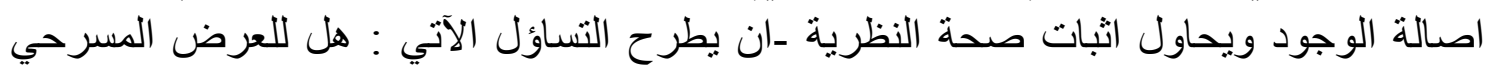

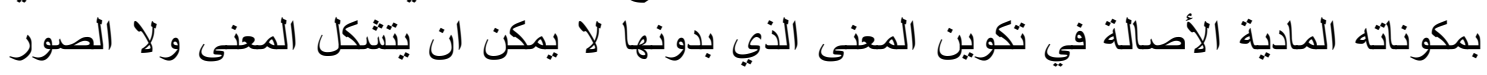

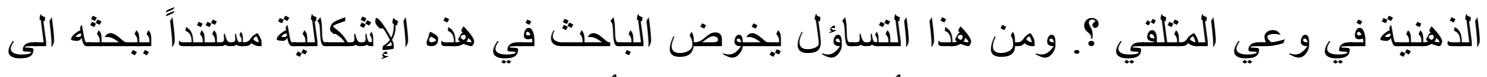

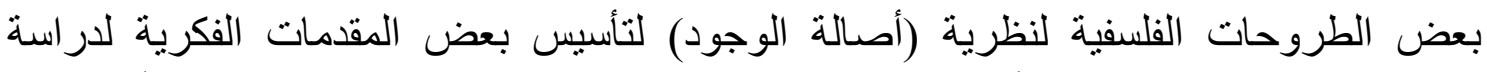

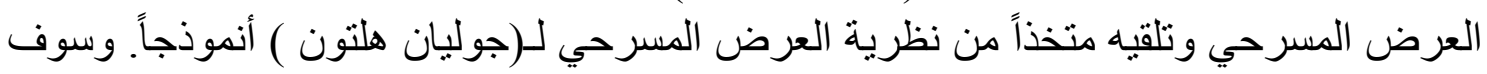

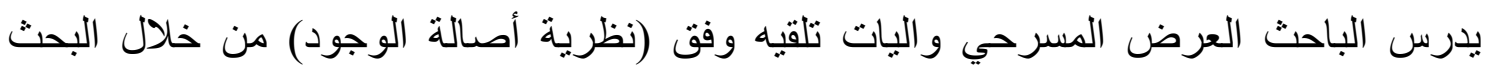
الموسوم ((الاشتغالات المعرفية لنظرية اصالة الوجود في العرض المسرحي (نظرية جولية اليان هلتون أنموذجا)). 
1- توظيف الطروحات الفلسفية الخاصة بنظرية اصالة الوجود في قراعة المنجز الفني لتوسيع دائرة البحث العلمي وتطبيق هذه المفاهيم الفلسفية في مجال الفنون المسرحية . لفئة

2- توجيه الإهتمام بالعرض المسرحي ومكوناتها و عناصر ها المادية ، التي يعمل المخرج وفريقه المسرحي زمن ليس بالقصير من اجل انتاج صورة مسرحية تدخل فيها الرؤية الفكرية والجمالية لرفع من ذائقة الجمهور، بعد ان تحولت هذه الجهود الى المرتبة الثانية ، إذ انصب التب الاهتمام بالمتلقي من خلال جعل ماهية التلقي وتأويل المعنى هي الأصل في النظريات الحديثة (نظريات

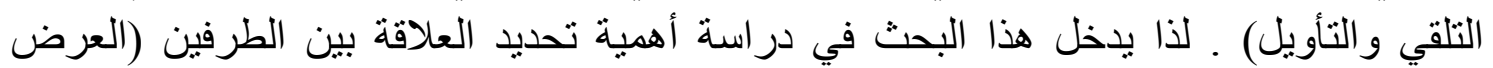
والمتلقي) .

هدف البحث :- يهدف البحث الى التعرف على آليات الاشتغالات المعرفية لنظرية اصالة الوجود في العرض المسرحي .

حدو البحث:- يتحدد البحث بموضوع الاشتغالات المعرفية لنظرية اصالة الوجود في العرض

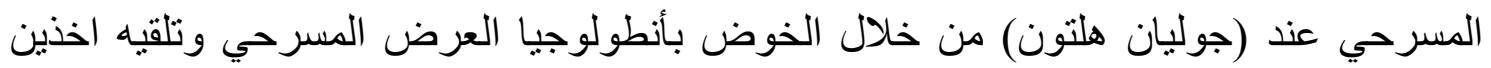

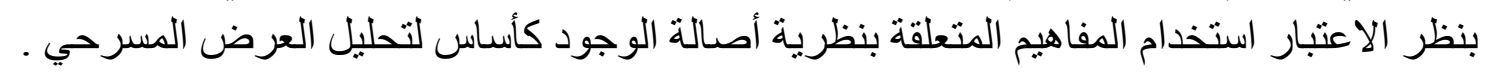

تحديل المصطلحات :-

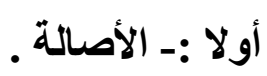

1- التعريف اللغوي :-" اصل - أصالة : كان له اصل / رسخ أصله/ كان من اصل شريف فهو

$$
\text { (1)" أصيل }
$$

2- التعريف القلسفي "الأصالة هي ان يكون للثيء أصل ، أي أساس بمعنى انه حقيقي غير مزيف

$$
\text { ولا منحول "(2) }
$$

1- التعريف اللغوي للوجود " وجد وجوداً الثيء عن عدم : كان وحصل ، فهو موجود "(3) 
"الوجود: مفهوم فلسفي يعني العالم الموضوعي ، أي المادة التي نوجد مستقلة عن الوعي

"الوجود أو الموجود بما هو موجود هو الثابت العين أو الذي يمكن ان يخبر عنه"(5)

التعريف الإجرائي لأصالة الوجود :- وهو الثيء الأصيل الموجود في العالم الموضوعي ،وهو

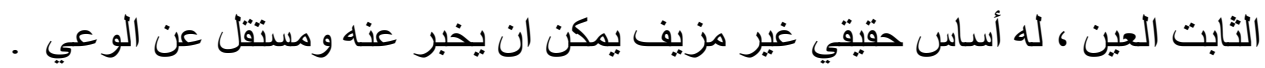
ثالثا:-ـ الماهية :-

1-التعريف اللغوي للماهية : هي " من الأمر أو الثيء: حقيقته وطبيعته وما يقوم به أو كل ما

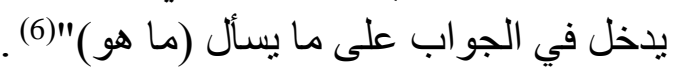
2-التعريف القلسفي للماهية:-

"من قولهم ( ما هو ) كما يقولون الكيفية والأينية من كيف وأين؟(...) والماهية نوعية

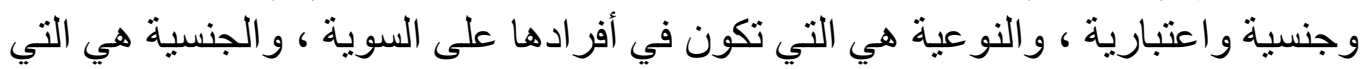

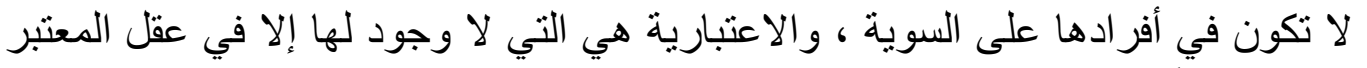

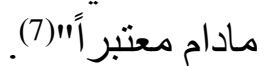

و الماهيات مفردها ماهية :" هي الصور الذهنية من حيث وضع بإز ائها الألفاظ ـ و الصورة

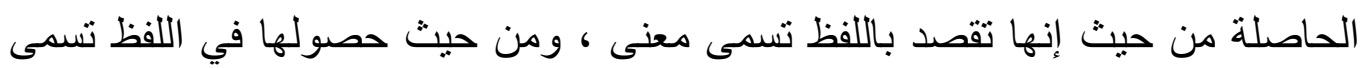

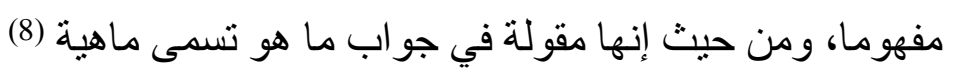

التعريف الإجرائي للماهية :- هي الصور الذهنية التي توضع بإزائها الألفاظ التي تقال عن ما هو ،

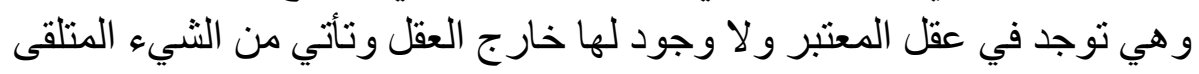

3 المنجد : المصدر السابق:ص888.

4 رزونتال .م ، ي ـ يودين : الموسوعة الفلسفية ، ترجمة: سمير كرم ، بيروت: دار الطليعة للطباعة والنشر ، ط2، 1980 :ص577. 5 ، محمد حسين : بداية الحكمة ، بغداد : مكتبة الكلمة الطيبة ،ط1، 2012،ص11.

$$
6 \text { المنجد : المصدر السابق :صف743. }
$$

8 التميمي ، قيصر : الفلسفة ، قم : دار الفر اقد للطباعة والنشر،ج2، ط1، 2010، ص22-23. 


\section{المبحث الأول}

\section{(الوجود والاشتغال الفلسفي للمصطلح ) .}

تتطلق تصورات الوجود من الفلسفات القديمة عند اليونان ما قبل (سقراط وأفلاطون وأرسطو)

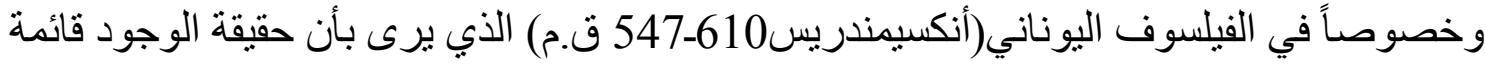
على اصل واحد وان كل الكائنات عائدة الى ذللك الأصل من خلال فكرة العود الأبدي و إلغاء فكرة

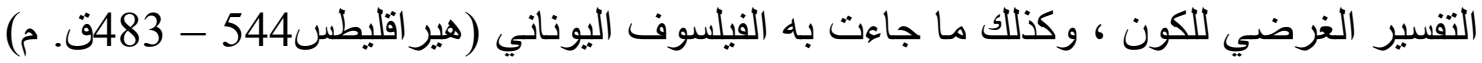
من تصور ات عن العالم المفرد و الصيرورة الواحدية التي تسمى أيضا (الفلسفة الاثباتية) التي تؤكد على وجود الأشياء وليس على إنكار ها.(9) وكذلك الفيلسوف اليوناني (بارميندس من القرنين السادس والخامس ق.م) الذي حاول ان يخوض في مجال الوجود حيث عد العالم كوحدة واحدة غير متجزئة و لا متغيرة بل هي مستقرة ، وقد عارض الإي الرأي القائل بوجودد" كثرة من الأثياء ،

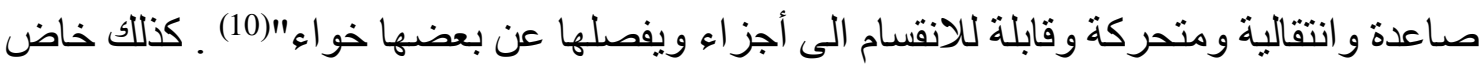

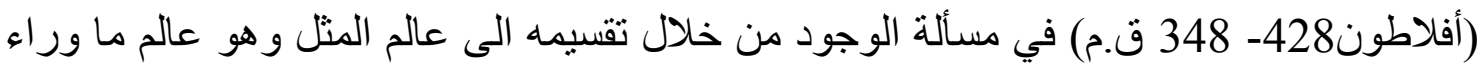

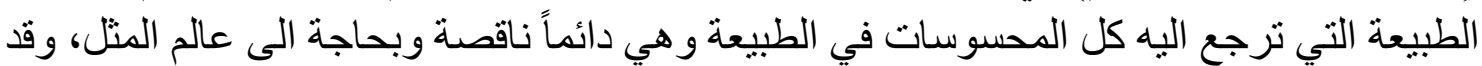

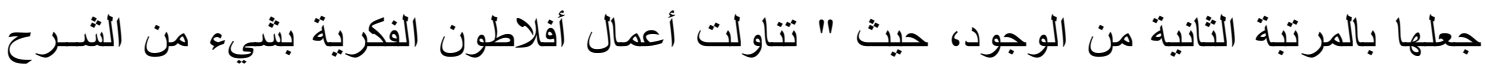

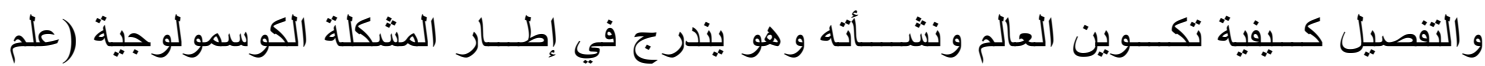

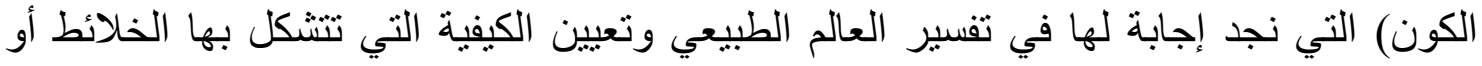
العناصر المختلفة التي بتركب منها العالم "(11). أما (أرسطو

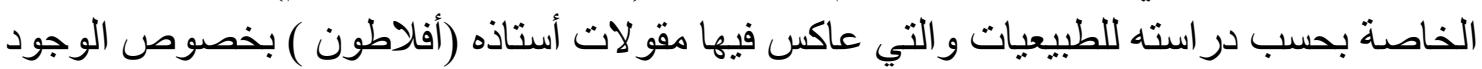

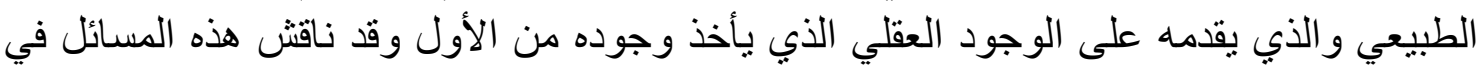

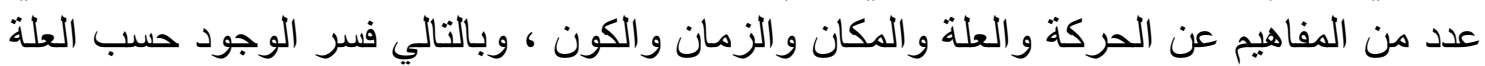
وغايتها.(12) لقد تكررت في القرون الوسطى أفكار بعض الفلاسفة وخصوصنا أفكار (أفلاطون

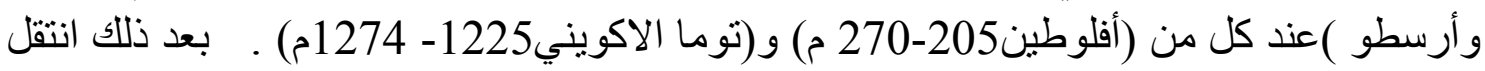

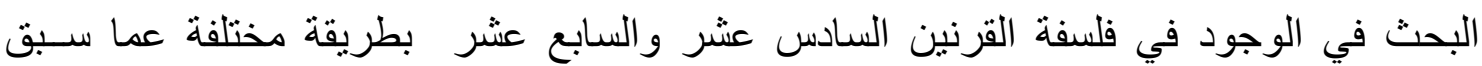
وبالأخص عنــد الفيلسوف الفرنسي (ديكارت 1596- 1650) الذي بحث الوجــود و الموجود من فئن

9 ينظر :عينات ،عبد الكريم : نيتثه والإغريق ،إثكالية اصل الفلسفة ، بيروت : الدار العربية للعلوم ناثرون ،ط1، 2010،ص88-71. 
خلال مقولته الشهيرة (أنا أفكر إذن أنا موجود) حيث أطلق صياغة جديدة في هذا البحث ، "فقد

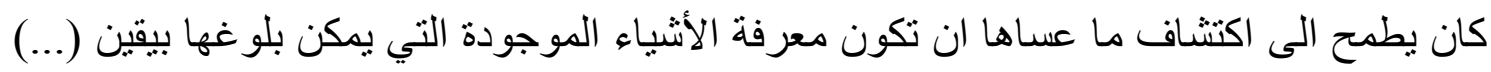
وذللك ما فعله (ديكارت) بطريقة بار عة ، إذ انه شرع في الثك في كل شيء يمكن الثك فيه فيه ، لكي

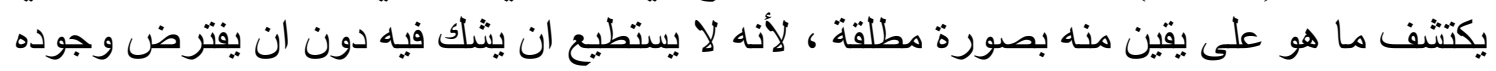
"(13) و البحث في هذه الوجود هي المقدمة المنطقية التي سعى إليها (ديكارت) في إثبات وجود الانه وصحت الأشياء.

أما الفيلسوف الالماني(نيتشه1844-1900) الذي تحولت فلسفة الوجود لديه الى فلسفة إلحادية فلسفة لا تبحث في المثل كما عند (أفلاطون) و لا بالعلة و الغاية كما عند (أرسطو) بل هاجم (نيتشه)

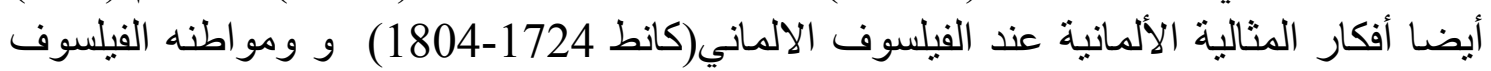

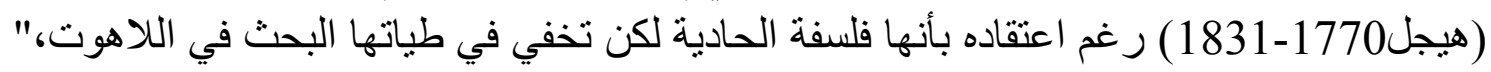

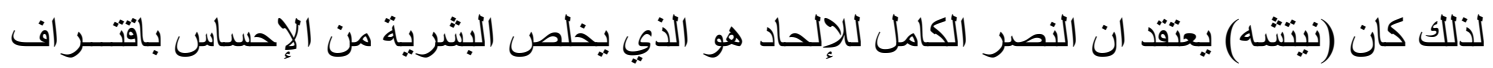

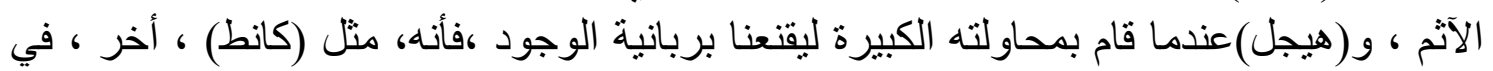

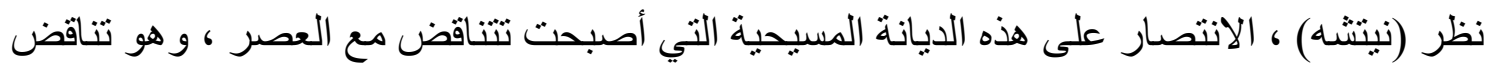

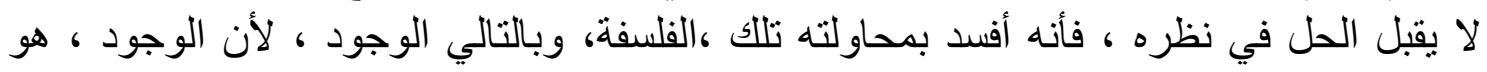

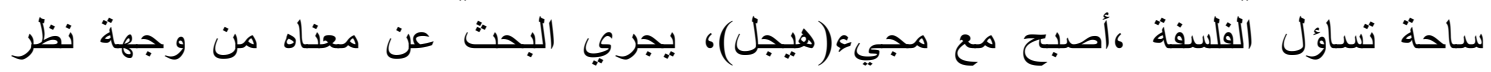

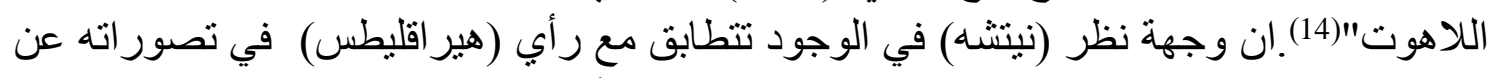

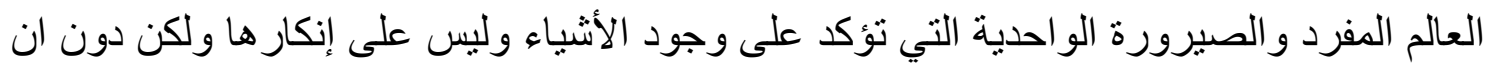

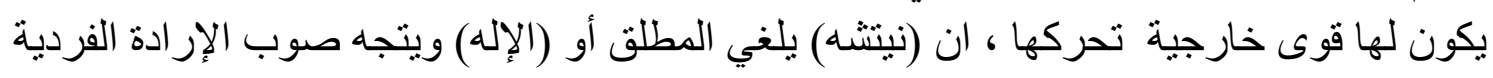

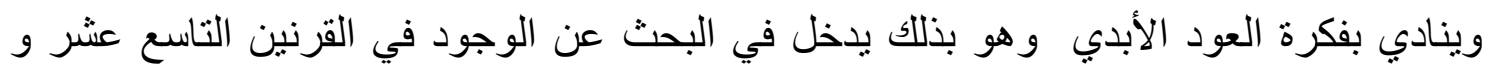
العشرين مع بداية فلسفة جديدة وهي الفلسفة الظاهراتية التي أطلقها الفيلسوف التئ الالماني(ادموند هوسرل1859-1938) وأثرت بفلاسفة آخرين من أمثال الالماني (مارنن هيدجر 1889- 1976)

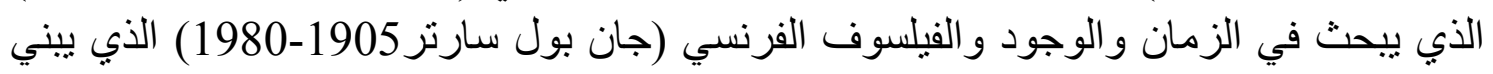
فلسفته الوجودية على مفهومي (الوجود و العدم ).

تنطلق فلسفة (هوسرل) في هذا المجال من أطروحته التي يرى فيها : أنه على الرغم من عدم

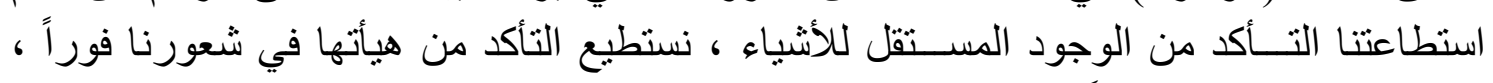

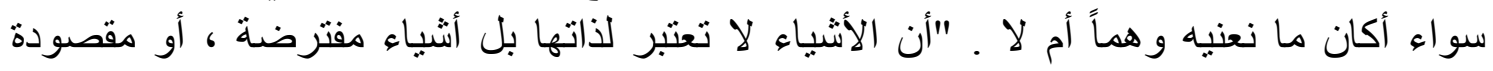
بالو عي و الإدراك ، كل وعي هو وعي بشيء ، في عملية التفكير ، أدرك أن فكري في هذه الحالة

13 رايت: وليم كلي: تاريخ الفلسفة الحديثة، ترجمة: محمود سيد احمد، بيروت: التتوير للطباعة والنشر والتوزيع ،ط2010،1.، ،ص97. 14 مفرج، جمال : الإرادة والتأويل ، تغلغل النيتشوية في الفكر العربي ،بيروت: الدار العربية للعلوم ناشرون ،ط1، 2009، ص56-57. 
يشير إلى شيء. ان وجود ثمة علاقة داخلية تربط عملية التفكير وموضوع التفكير ويعتمد أحدهما

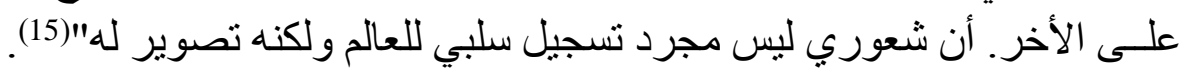

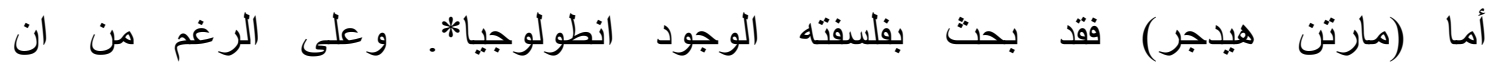
الظاهر اتية(فينومينولوجيا) قد أطلقها (هوسرل ) كأساس لفلسفته " لكن ما كان لها ان تبلغ ما بلغته من انتشار على خارطة المباحث الفلسفية المعاصرة إلا بعد ان لبست ثوباً (انطولوجياً) مميزاً حاول فيه (هيدجر)ان يقدم توازناً بين السؤال الباحث عن الكينونة وبين طرق تحقيق هذا السؤ ال .

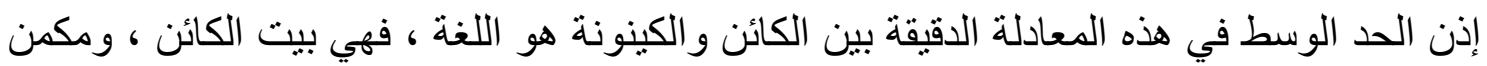

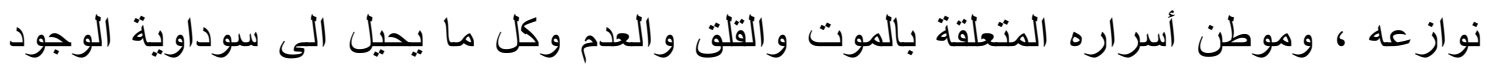

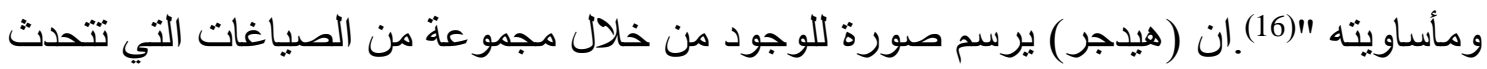

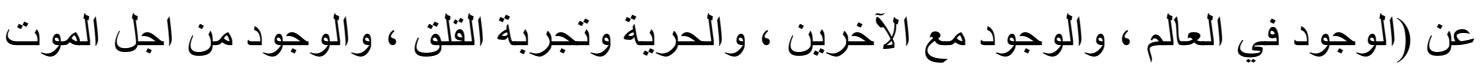

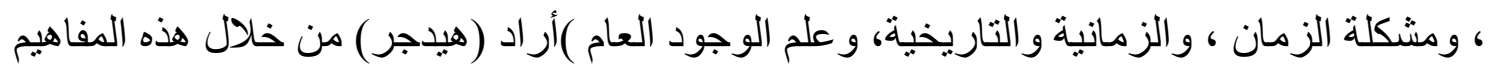

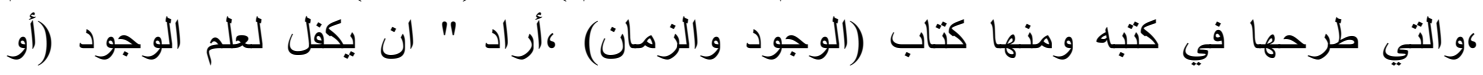

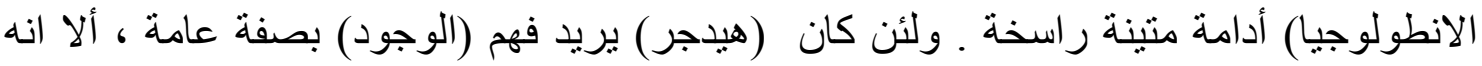

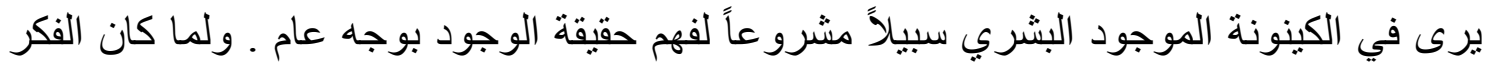

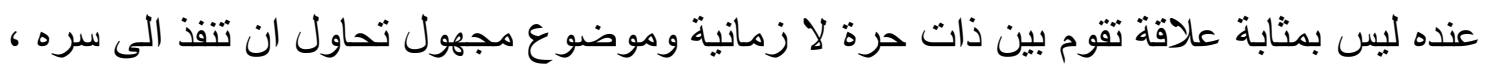

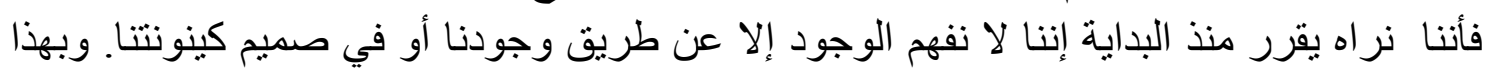

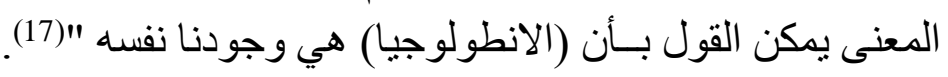

أما الوجود عند (سارتر) فتتضح ملامحه في كتابه (الوجود و العدم ) الذي يرى فيه "بأن الإنسان

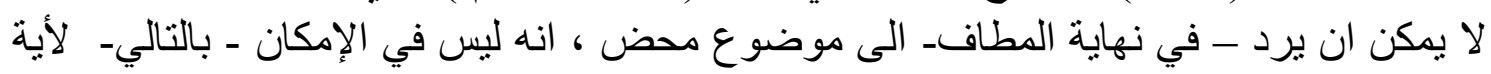

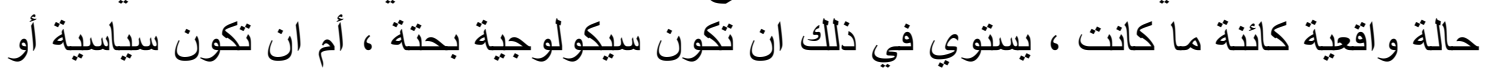

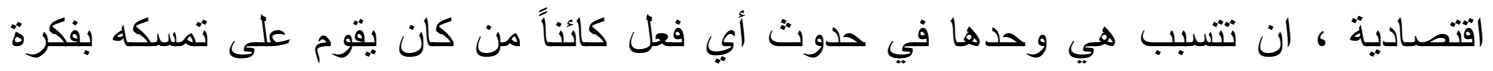

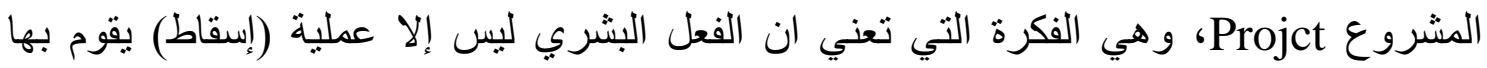

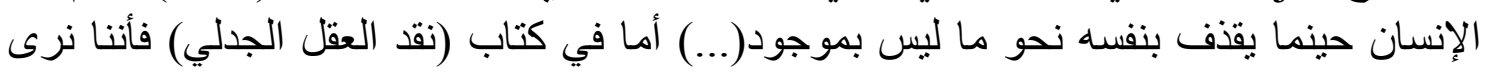

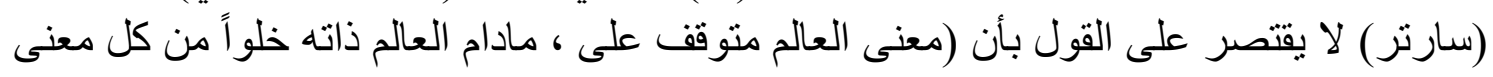

15 أيغلتن ، تيري : مقدمة في النظرية الأدبية ، ترجمة د ـ عاصم إسماعيل الياس ،بغداد : دار الثؤون الثقافية العامة ، 1992 ، ص 63

16 أحمد ، إبر اهيم : انطولوجيا اللغة عند مارتن هيدجر ، بيروت : الدار العربية للعلوم ناشرون ،ط1، 2008،ص10-10. 171إبر اهيم ، زكريا: دراسات في الفلسفة المعاصرة ، القاهرة : مكتبة مصر ،1987،ص400. 
، وأنا الذي أخلع عليه كل ما له معنى ) بل بحاول ربط فكرة المشروع Projct بأفكار ديالكتيكية ماركسية كفكرة (السلب) Negativite أو الفعل وفكرة التعالي أو المجاورة "N(18). ان فلسفة الوجود في الفكر الغربي ابتداءاً من الفكر اليوناني القديم وفي عصر الأنوار وفي الفلسفة

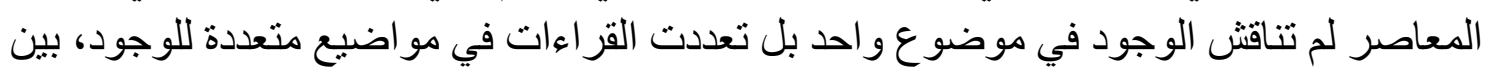

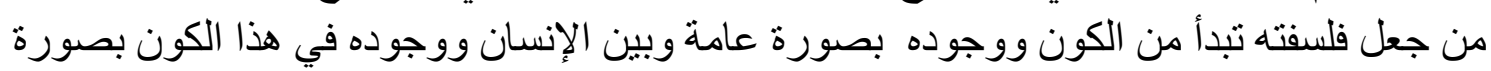

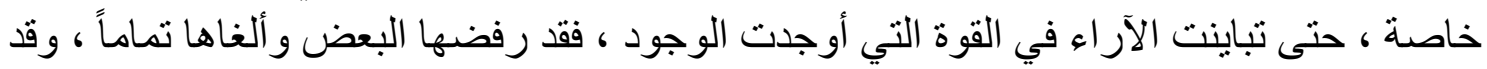

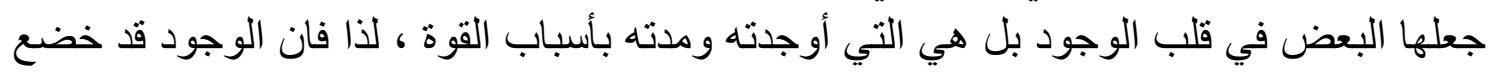

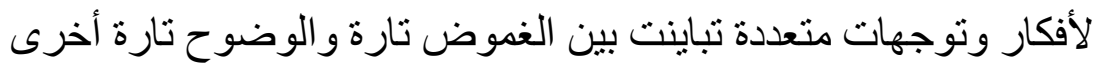

المبحث الثاني :- ( نظرية أصالة الوجود في القلسفة الإسلامية ) أولا:- مصادر نظرية أصالة الوجود ـ

لقد نظر الفلاسفة في العالم الإسلامي نظرة مختلفة عن النظرة الغربية وخصوصاً في المرحلة التي تز امنت مع نشوء الإسلام وقيام أركان دولته وما بعدها، حيث اتجه الفلاسفة في العالمين العربي

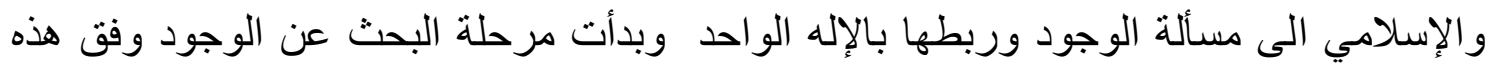

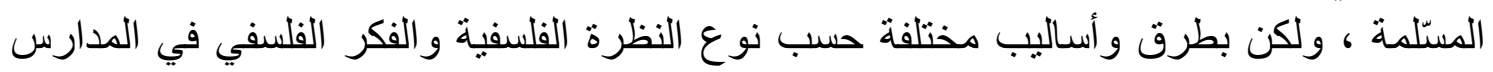
الإسلامية المختلفة ،علماً بان هذه الطرق الفلسفية استندت في اغلبها الى المصادر الفلسفية الفية اليونانية وخصوصاً ما عرف بالاتجاهين الرئيسين في الفلسفة اليونانية (الأفلاطوني أو ما أطلق عليه في الإني

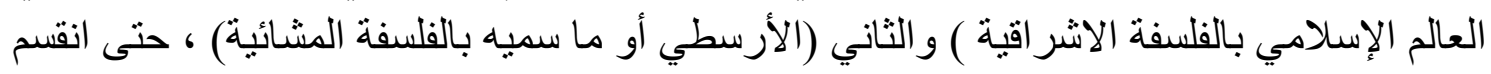
فلاسفة المسلمين الى إثراقي و مشائي ، وبالتالي أصبحت النظرة الى الوجود التأخذ احد الاتجاهين . ان القول بأصالة الوجود أو أصالة الماهية توزعت بين الفريقين مثلما توزعت المرجعيات الفلسفة اليونانية فيها ايضاً ، حتى أصبحت بلاد الغرب الإسلامي ترجع الى فلسفة (أرسطو) وخصوصاً

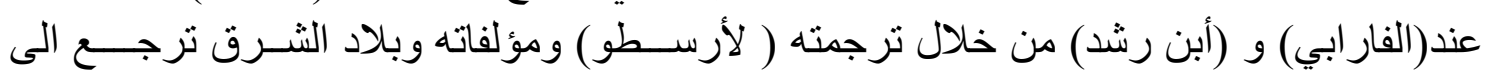

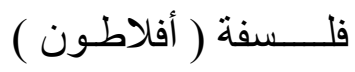

وخصوصاً مع تبني شيخ الإشراق (السهروردي*) لمقولات (أفلاطون) الفلسفية في إثبات أصالة الماهية.

لقد انطلقت فلسفة الأصالة و الاعتبار بين الوجود و الماهية من أراء كل من (أفلاطون وأرسطو ) ،

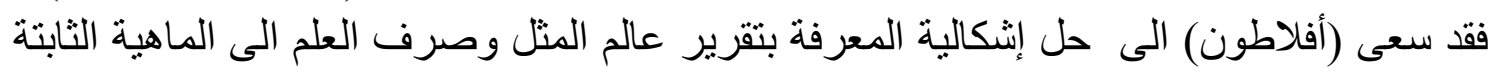


،الأصيلة. و على الرغم من ذلك ،فأن (أرسطو) ، هو أول من وضع (الأرغون) في محاولة لضبط التها

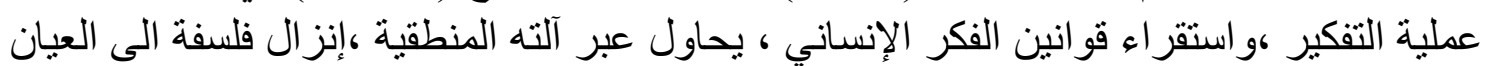

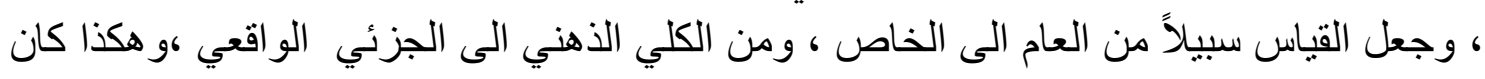

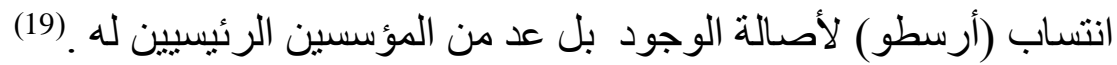

ان نظرية أصالة الوجود في الفلسفة الإسلامية لم تطلق بشكل صريح وو اضح بل كانت هناك أراء

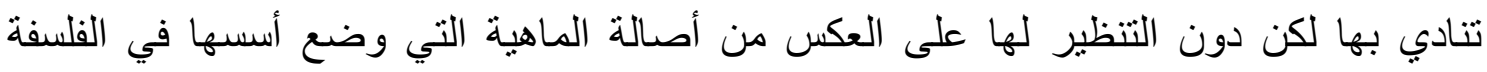

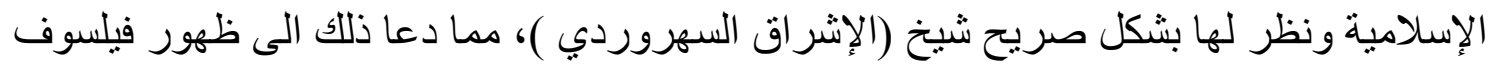

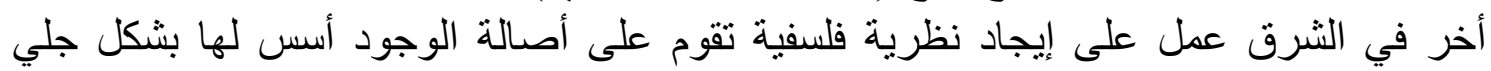
الفيلسوف (صدر الدين محمد) وموقفه هذا يعد موقفاً نقيضاً لما دأبت علية الفلسفة الإسلامية في

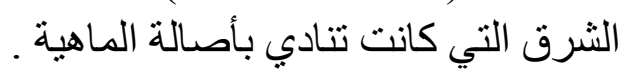

ان المصسادر التي استقى منها (صدر الدين ) فلسفته في الوجود هي: (الفلسفة المثـائية ، وتر اث

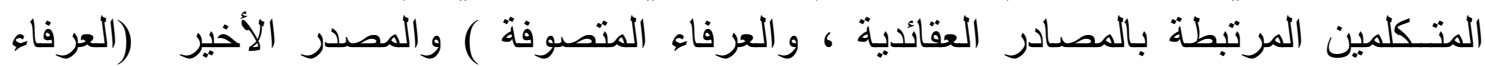

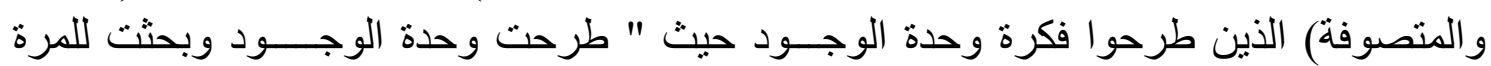
الأولى وتمت صباغة أصولها النظرية بشكل تام في تراث الثيخ (محي الدين بن عربي) ، ثمدئ أضحت هذه المسألة محور اً لأفكار (جلال الدين الرومي)في كتابه الثهير (المثنوي)،وبعد ذلك من

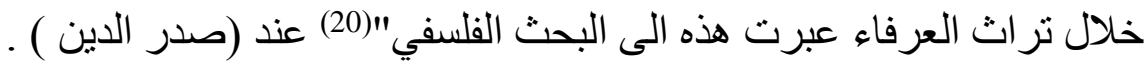

ثاتياً:- نظرية اصالة الوجود

تقوم نظرية أصالة الوجود في الفكر الاسلامي على ثناثة مر اتب للوجود ، حيث سعى الفلاسفة الى الى إثباتها و هذه المر اتب الثلاثة هي :-

أو لا:- الوجود الحق : "وهو الوجود المجرد عن جميع الألقاب والأوصاف حتى عن هذا الوصف .

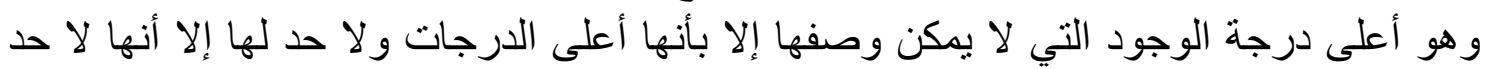

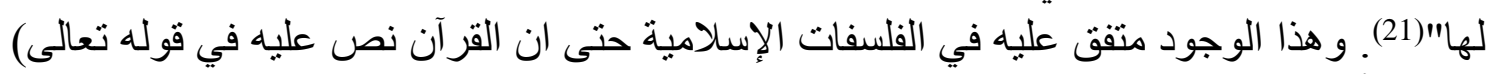

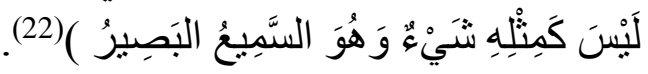

19 ينظر : هاني، إدريس : ما بعد الر اشدية ، بيروت: مؤسسة دائرة معارف الفقه الاسلامي ، 2000،ص38 20 الرفاعي ، عبد الجبار : في أصالة الوجود واعتبارية الماهية / انترنيت : موقع موسو عة دهشة ، 2012/12/15 ، ص2-2. 21 محمد حسين : بداية الحكمة ، المصدر السابق ، ص21. 22 القرآن الكريم : سورة الثورى ، الآية 11 . 


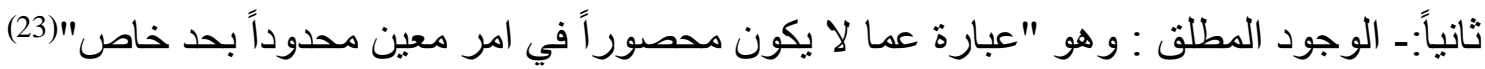
ووهذا الوجود يقع خارج المحسوسات كما هو الأول ، ويختص هذا الوجود بخصود الوصيات مر اتبية. غير خارج عن المر اتب نفسها

ثالثاً:- الوجود المقبد : وهو خلاف الوجود المطلق كالإنسان والفلك و النفس والعقل وجود الأعيان

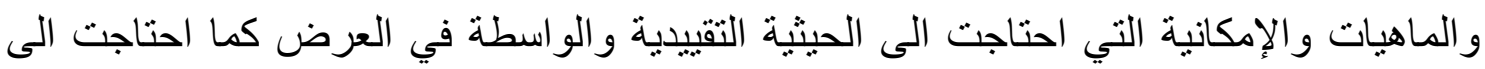
الحيثية التعليلية في حمل الوجود عليها (24) ـ وهذا الوجود هو الذي يقع في عالم الإمكان وهو الموضوع الذي سيركز عليه البحث ، وهذا النوع الثالث من الوجود هو المتمثل في عالم الطبيعة و المحسوسات ويسمى بالوجود الممكن لإمكان حواس الإنسان من أدركه و التعامل مع معطياته

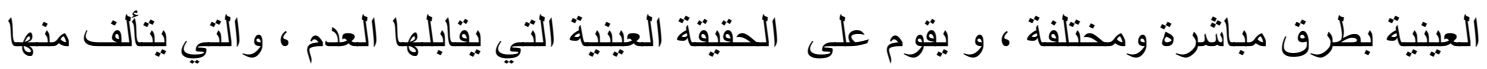

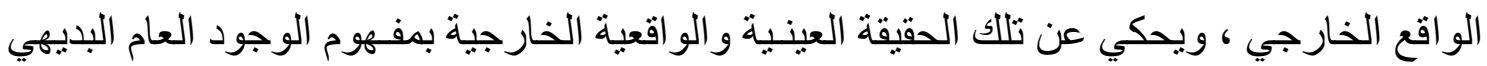
الذي يعد من المفاهيم الفلسفية. تكون أصالة هذا الوجود نابعة من وجودده بحد ذاته في الحضور

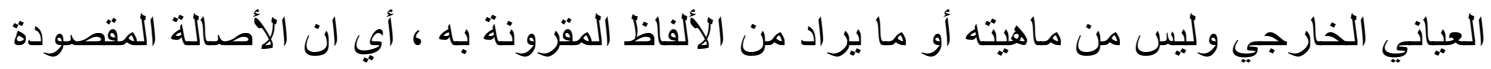

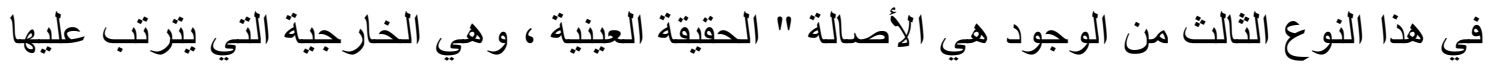

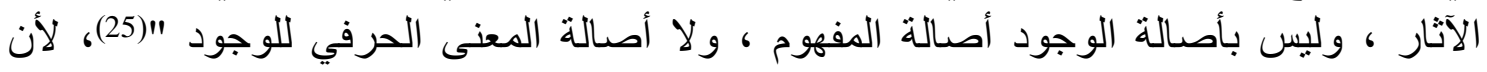
المعنى الحرفي سيكون مرتبط بماهيته المرسومة في ذهن المتلقي للثكل الوجودي للموجود. ان الآثار المترتبة على الثكل الوجودي للموجود هي التي تعطي الصور الخارجية له وتشكل هيئته

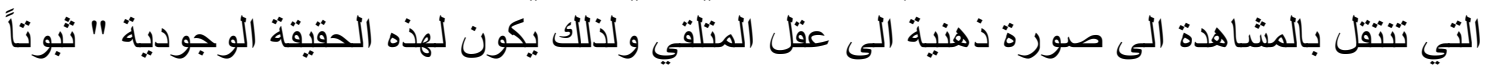

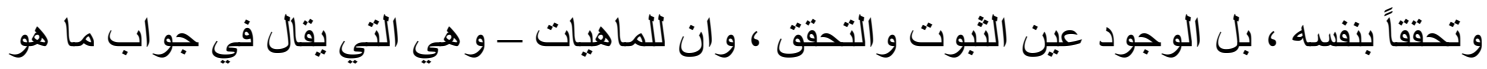

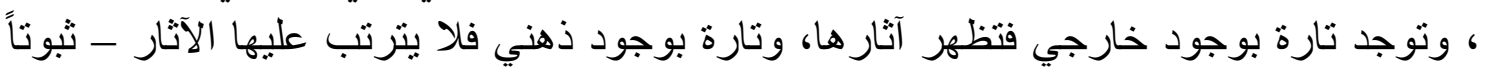
وتحققاً بالوجود ، لا بنفس ذاتها ، وان كانا متحدين في الخارج، ان المفاهيم الاعتبارية العقلية ـ

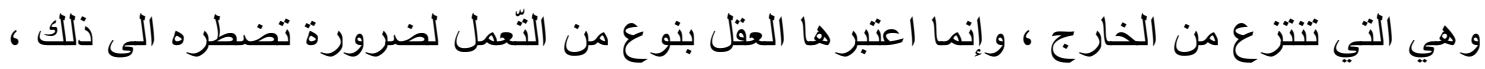
كمفاهيم الوجود و الوحدة و العلية ونحو ذللك - أيضا لها ثبوت بثبوت ونئ مصاديقها المحكية "(26).

23 سميح، دغيم : موسوعة مصطلحات صدر الدين الشيرازي، سلسلة موسوعات اعلام الفكر العربي والاسلامي ، قم : منشورات ذوي

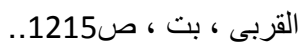
24 ينظر : نفسه ص1215.

25 الرفاعي ، عبد الجبار : في أصالة الوجود و اعتبارية الماهية / انترنيت : موقع موسوعة دهشة ، تاريخ المقال 2012/12/15 ، 
ان للوجود حقيقة عيانية مستقلة بذاتها وان الماهية هي أمر يرجع ليس لجوهر الموجود بل لما

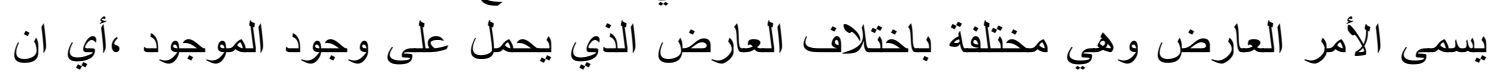

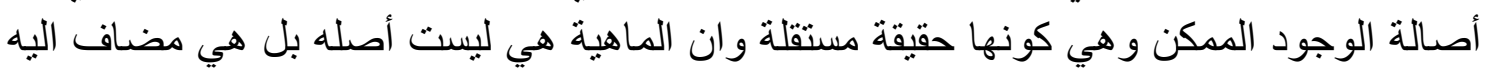

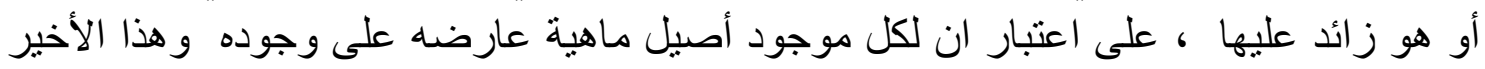

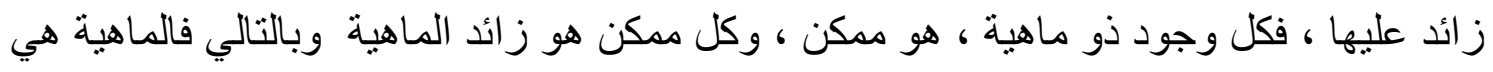

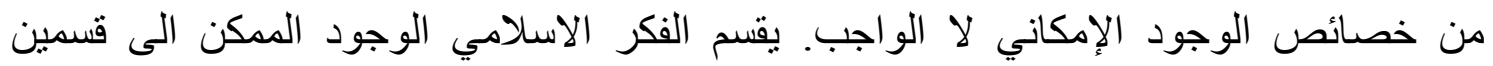

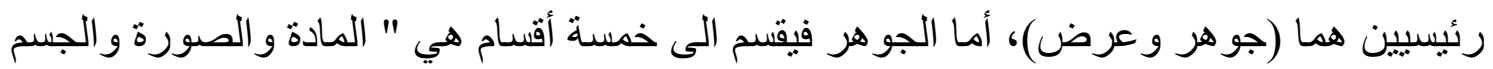

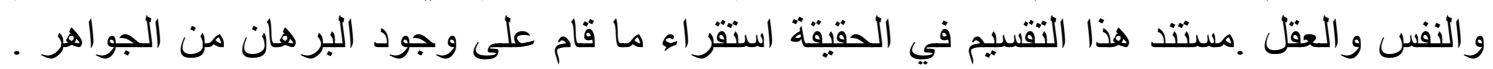

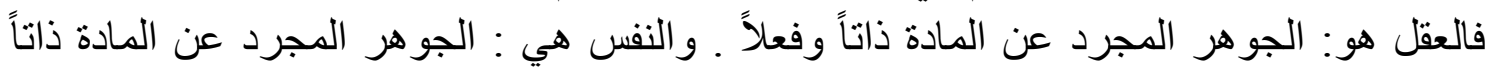

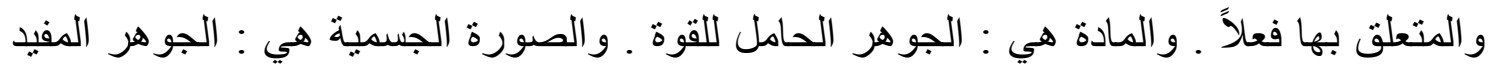

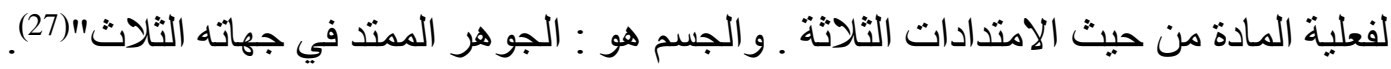

أما (العرض) فقد قسمه الى تسعة مقولات وهي (الكم والكيف والاين ومتى والوضع و الجدة و

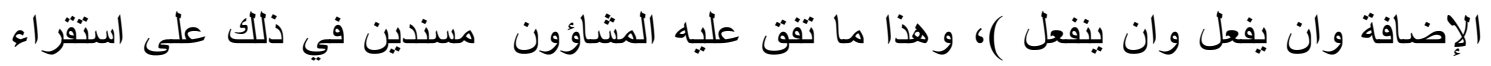

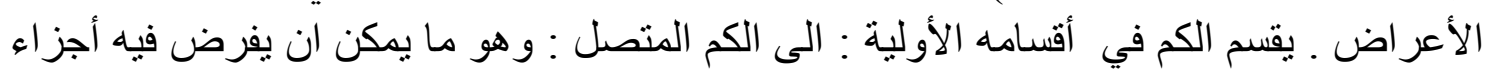

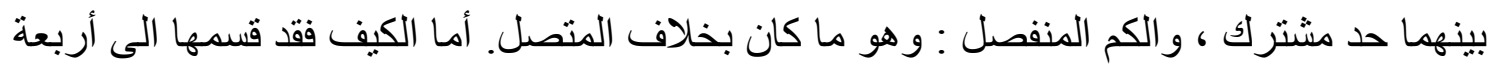

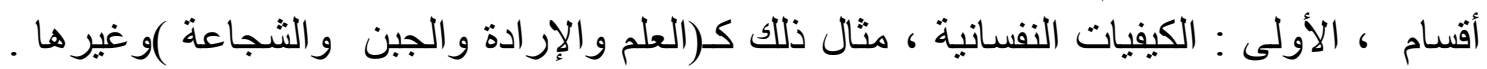
و الكيفيات المختصة بالكميات ، مثال (الاستقامة و الانحناء و الثكل ). و الكميات الاستعدادية، مثنال

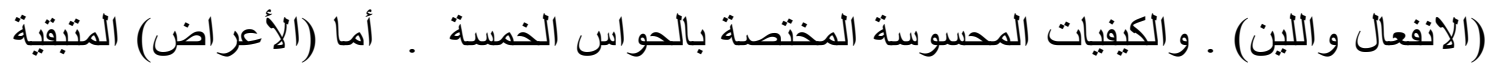

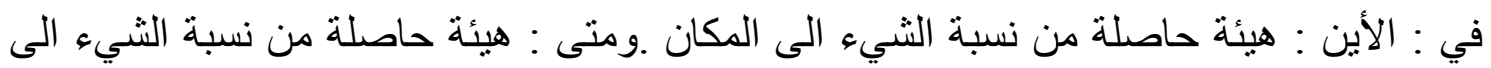

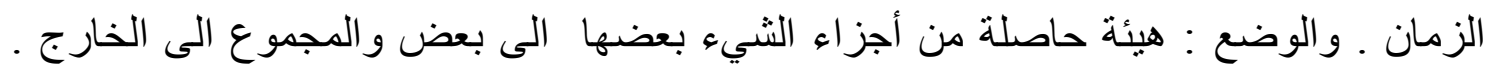

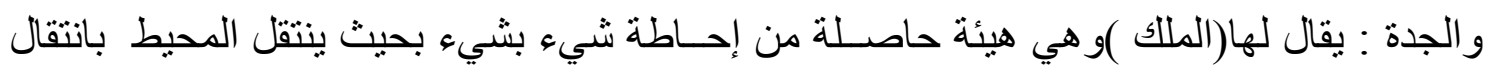

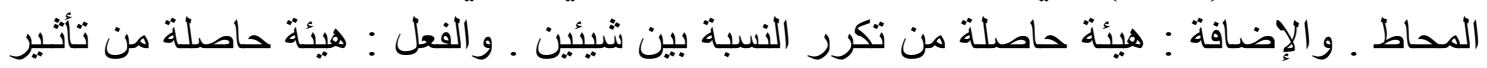

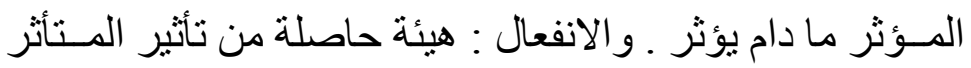

ما دام يتأثز . (28)

يرى الباحثون في الفكر الاسلامي بأن للوجود مفهوم عام ينتزع من الوجود العيني ولهذا يضع

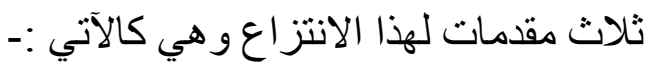


1- عند مواجهة الثيء الواقعي فأننا نكون أما مفهومين الأول هو الوجود وهو مشترك بين

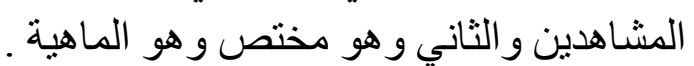

2- ان المفهوم المشترك بين المشاهدين للثيء هو الوجود و المختص هو الماهية وبالتالي يقع هذا

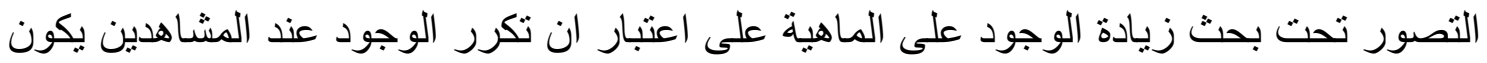

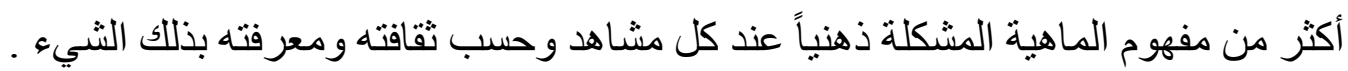

3- ان انتزاع أي مفهوم حاكي عن الثيء المشاهد يتوقف على مدى تحقق الأمر المنتزع عنه

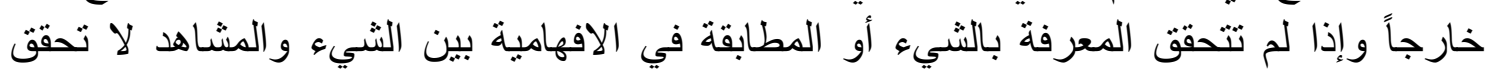

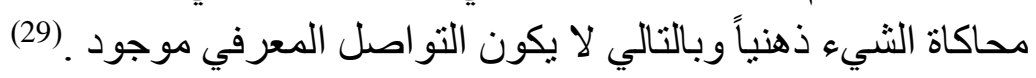

ويضع المفكر الاسلامي للوجود مر اتب يجعلها موزعه ليس فقط بين الداخل والخارج أو بين الوجود و الماهية بل تأخذ صيغ أخرى وهي لاصدي كالآتي:-

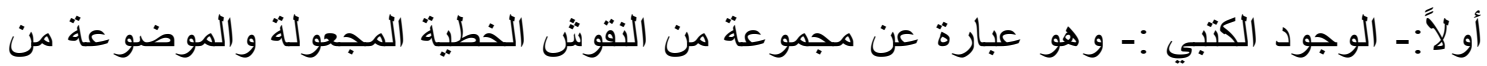

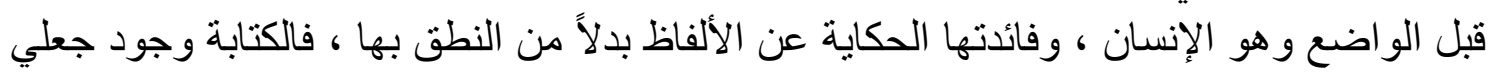
اعتباري حالك عن الوجود اللفظي للأشياء.

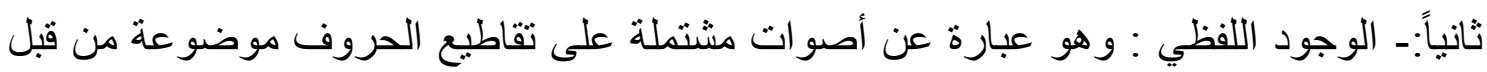

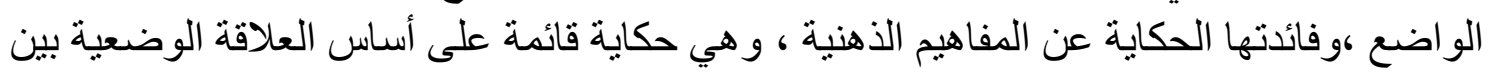
اللفظ وبين المفهوم في الذهن.

ثالثا:- الوجود الذهني :- وهو عبارة عن مجموع المفاهيم الذهنية الحاكية عن مصاديقها في عالم

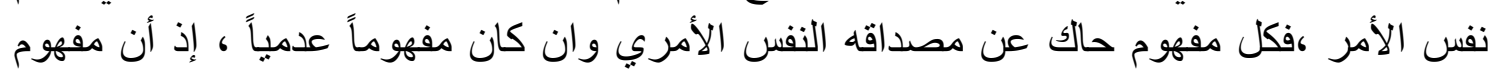
العدم يحكي مصداقه في نفس الأمر وإن لم يكن لله مصداق في الو اقع الخارجي"(30). مؤشرات الإطار النظري:-

1. الوجود هو وجود الأعيان و الماهيات التي تحتاج الى حيثية تقييدية وو اسطة في العرض ، وكذلك تحتاج الى حيثية تعليلية في حمل الوجود عليها ويكون أما بالحمل الذاتي أو بالحمل

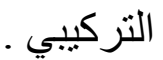


2. ان للموجود آثار تترتب عليه صور خارجية وصور داخلية ذهنية ، وبذلك يتحول هذا الوجود الى وجودين خارجي يترتب عليه أثنار ووجود ذهني لا يترتب عليه آثار في داخل

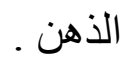
3. ان الوجود الذهني لا يأخذ شكله في داخل الذهن دون وجود ماهية للوجود الخارجي ، هذه الذه إنه الماهية تكون مضافة الى الوجود الخارجي وكذلك زائدة عليه وتكون رابطة بين الوجودين الخارجي و الذهني. 4. ان الماهية هي صورة وشكل لا تعود الى جوهر الوجود بل الى العرض الناتج عن الوجود

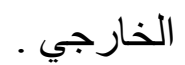

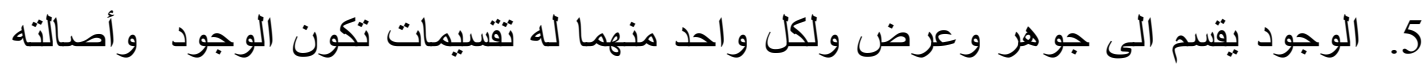

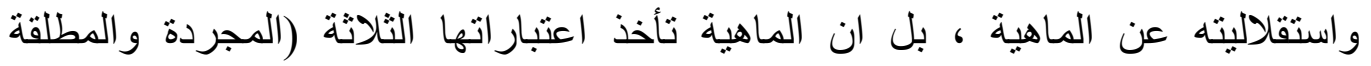
و المخلوطة) من الوجودات الثناثة (الحق ، المطلق ، المن ، المقيد ).

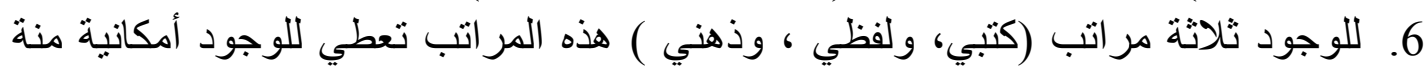

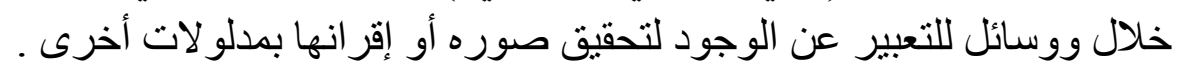

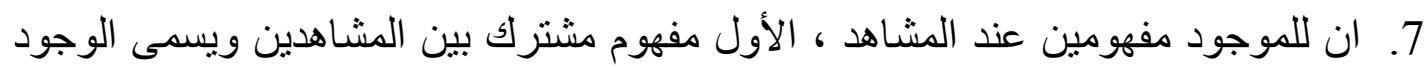

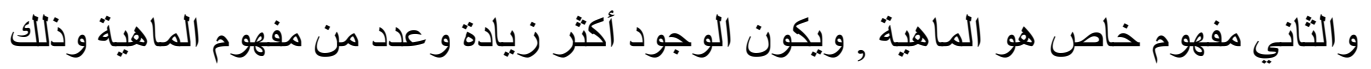

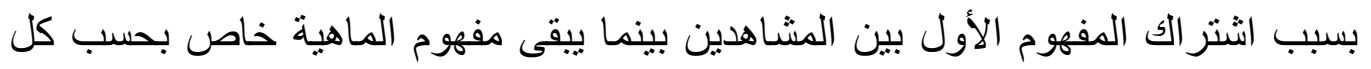

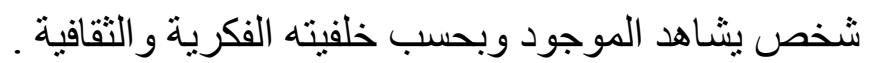

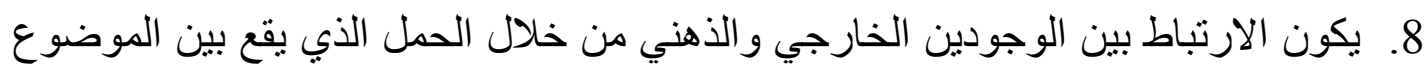
و المحمول ، ويكون أما حمل ذاتي من ذات الموضوع الوني أو الون حمل نركيبي من خارج ذات الموضوع .

$$
\text { الفصل الثالث (إجراءات البحث) }
$$

$$
\text { يتناول الباحث في هذا الفصل امرين هما :- }
$$

بناء الاجر اءات الخاصة بالتحليل و هي( عينة البحث القصدية ، منهج البحث ، اداة البحث )

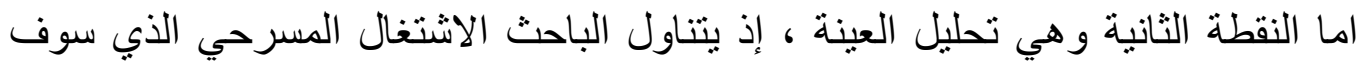

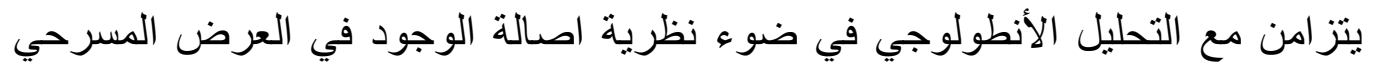

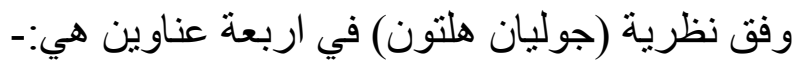

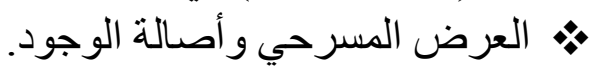

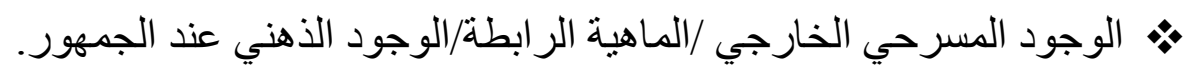

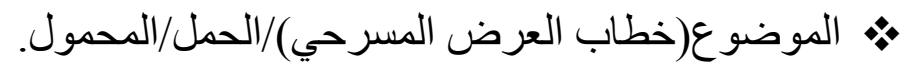
• مر اتب الوجود في العرض المسرحي(الكتبي/اللفظي/الذهني). 
يتخذ البحث من نظرية جوليان هلتون في العرض المسرحي مبداناً لتطبيق مبدأ أصالة الوجود و اعتبارية الماهية عند المتلقي , ويتخذ منها عينة قصدية لبحثه كون هذه النظرية تحتوي على: 1-ان نظرية العرض المسرحي لـ(جوليان هلتون) تناقش ,وحسب رأيه ــ در اسة فن الأداء وظاهرة

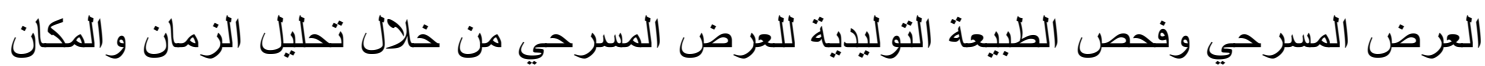
و الفعل فيه. 2- در اسة فن العرض المسرحي في أمرين هامين :البحث في الكيفية يتم تحويل اللعبة المسرحية الى واقع حقيقي .

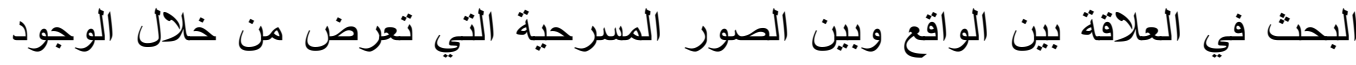
الحقيقي للفعل الإبداعي المسرحي

3- يتشكل العرض المسرحي لايه من خلال متو الية ثلاثية هي : التركيز و التكثيف والنظرة النسبية القى العالم.

4-ان هذه النقاط الثلاثة التي تنشير الى الوجود الممكن في نظرية العرض المسرحي عند (هلتون) هل يمكن استثمار ها في إيجاد علاقة بين نظرية العرض المسرحي ونظرية أصالة الوجود؟ ، في في ضو ء ما يريد الباحث در استه

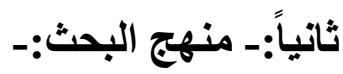

اعتمد الباحث منهج البحث الوصفي التحليلي في دراسة العينة.

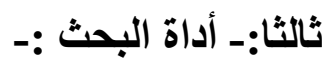
يتخذ الباحث من:- - 2 - 2 1. مؤشرات الإطار النظري

2. الدراسات النظرية حول نظرية جوليان هلتون وخصوصاً كتابه (نظرية العرض

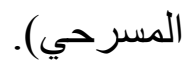

كأداة للبحث من أجل در اسة العينة. 
ينطلق (جوليان هلتون) في نظريته المسرحية من السؤال الآتي , إذا كان المسرح هو فن الأداء الحي التلقائي فهل يمكن دراسته ؟ وهل من المطلوب هن در استه؟ فتأتي الإجابة بنعم ، وتحديد ما دابه

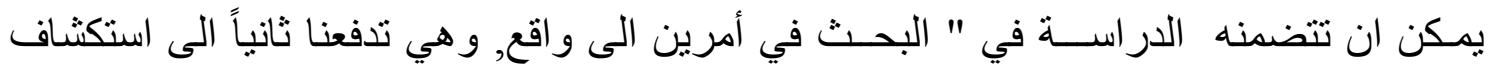

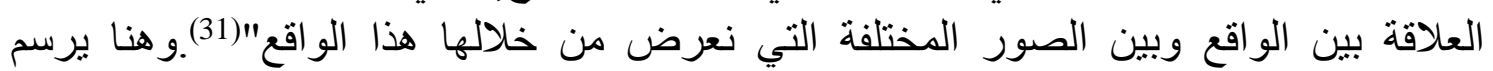

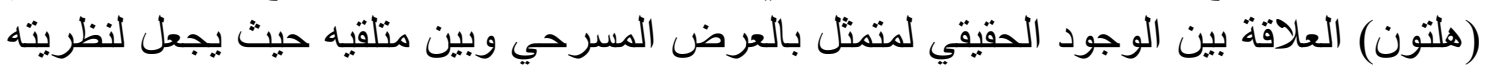
مدخلين هامين هما:-

1. استكثاف العلاقة بين الو اقع وبين الصور المختلفة التي نعرض من خلالها هذا الواقع ،أي

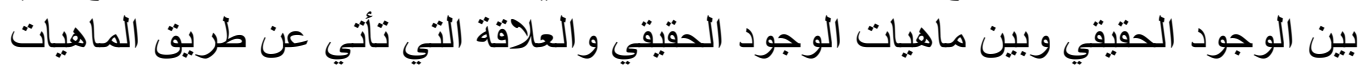
الر ابطة .

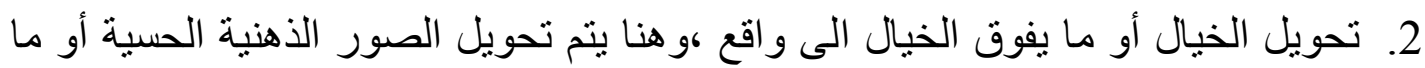

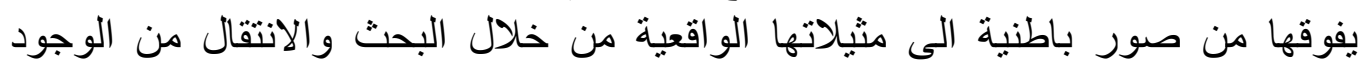

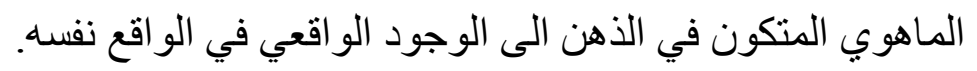

و ون هذين المدخلين ننتقل الى ملامح نظرية العرض و ارتباطها بأصالة الوجود الممكن أو (المقيد) رحيث يستعرض (هلتون) نظريته من خلال سبعة فصول في كتابه (نظرية العرض المسرحي)

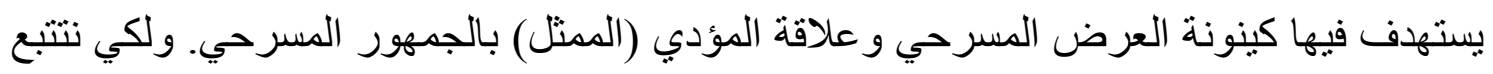

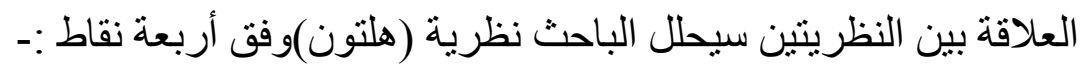
أولا:- العرض المسرحي وأصالة الوجود:-

\section{1. جوهر الوجود الممكن وعناصره الخمسة في العرض المسرحي:-}

تتطلق نظرية أصالة الوجود في إثبات جوهر الوجود من خمسة عناصر وهي كما يأتي:-

أـ الجسم :الجوهر الممتد في جهاته الثثلاث (الطول، العرض ،الارتفاع) وهذه الجهات

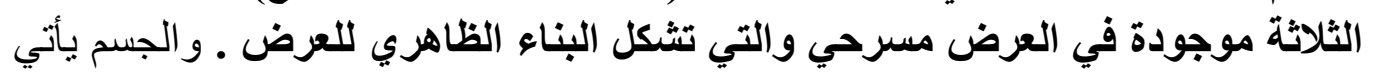

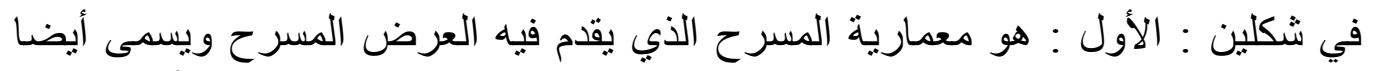

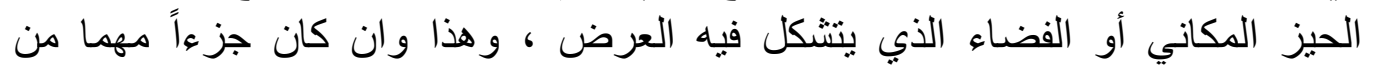

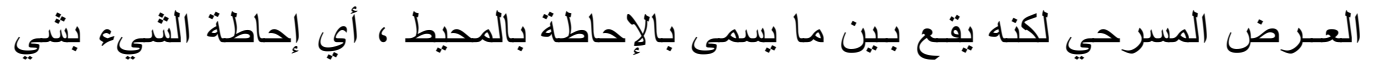

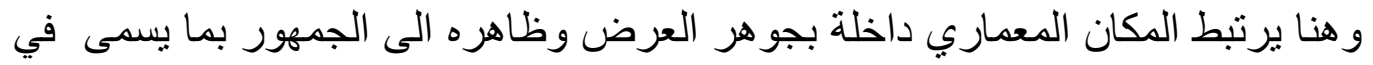


نظرية أصالة الوجود بعرض ، وسوف يتناوله الباحث في فقرة الأعر اض التسعة ـ و الثاني

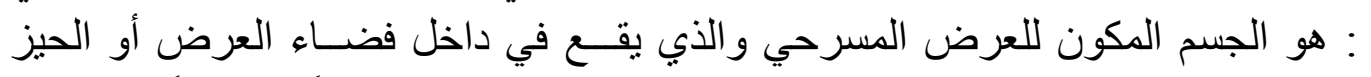

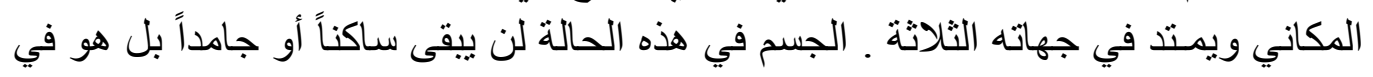

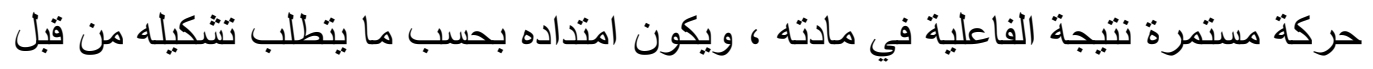

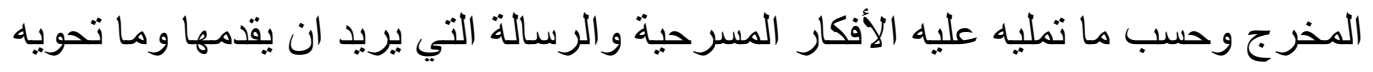
من جوانب فكرية والجمالية وهنا يرى هلتون في جسم العرض بأن تشكليه من الثروط لتانه

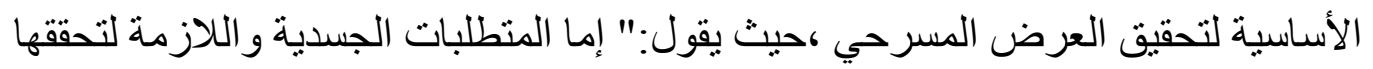

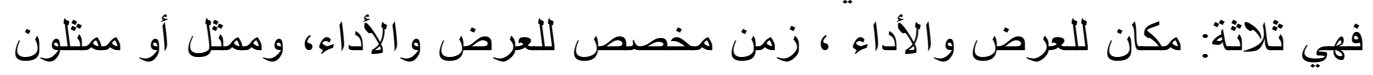

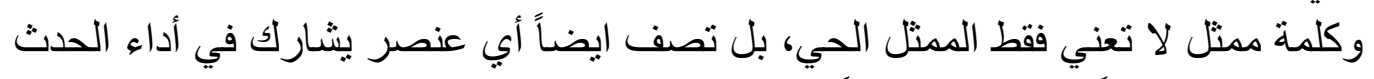

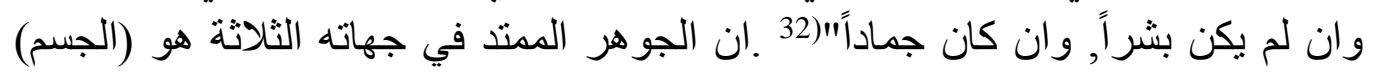
الداخلي الذي يكون وجود العرض المسرحي ولبناته الأساسية المندمجة كلها في في بناء

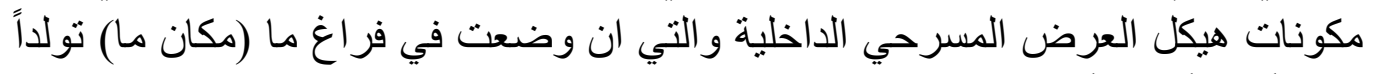

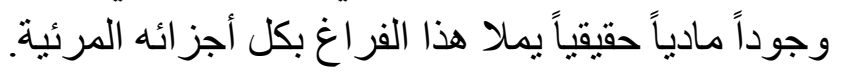

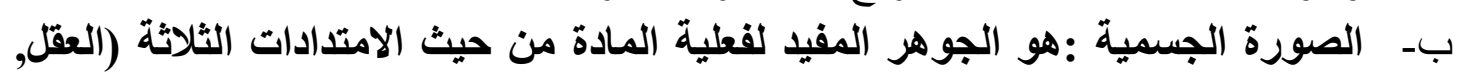
النفس، المادة). حيث يصاغ العرض المسرحي عادة في إطار صوري خارجي يمثل فئل

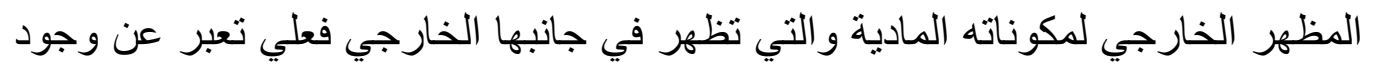
مادي واقعي في الحيز المكاني , هذه الصورة الجسمية للعرض المسرحي تعطي انطباع

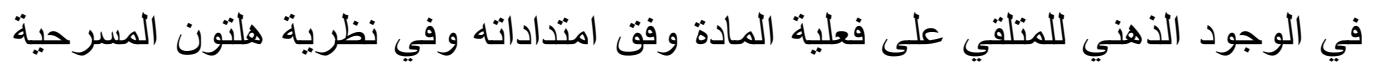

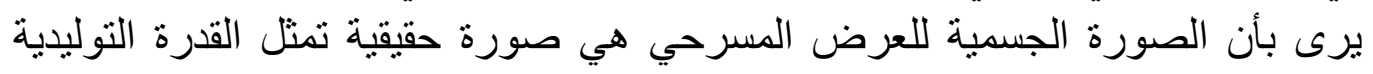

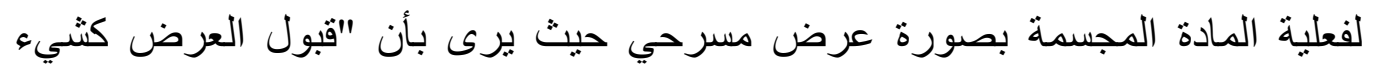

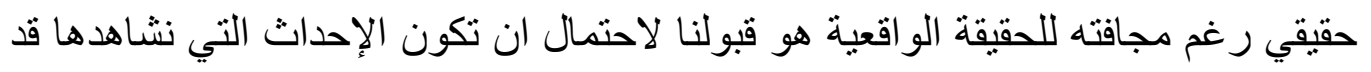

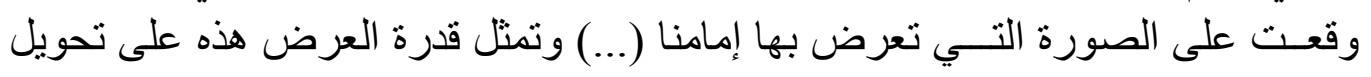

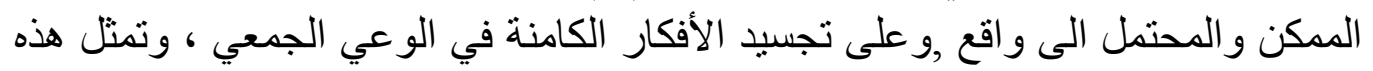

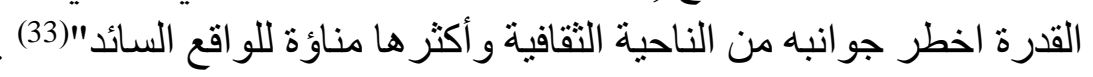

ان امتدادات الصورة الجسمية في العقل تظهر في الأفكار الكامنة في الوعي الجمعي التي يعبر

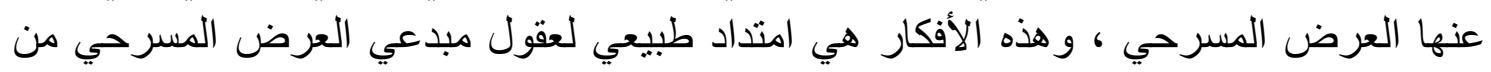

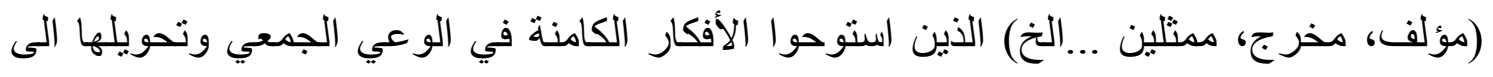

32 هلتون ,جوليان: المصدر السابق ,ص35. 33 هلتون ,المصدر السابق ،ص71. 
منتج إبداعي يحاكي تطلعات الجمهور المسرحي الذي هو شريحة متنوعة ممثلة للوعي الجمعي للمجتمع.

وجوهر النفس المتعلقة بمادة وجود العرض الحقيقي وهذه النفس التي هي جوهر مجرد عن ذاتاً

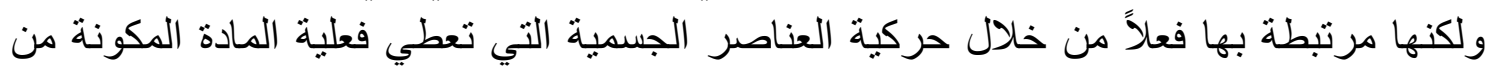
الوجود الممكن للعرض المسرحي وبالتالي فأن جوهر النفس في العرض بكمن في في سلوكية الحركة الموضوعية وما تعطيه من انطباع للمشاهد عن هذا العرض او ذالك بحسب انتماءاته الفكرية

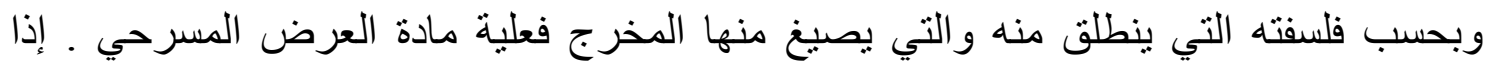

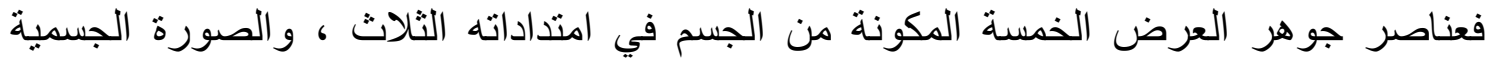
الممتدة في العناصر الثناثة المنبقية (العقل، النفس والمادة) هي من تعطي للعرض المن المسرحي

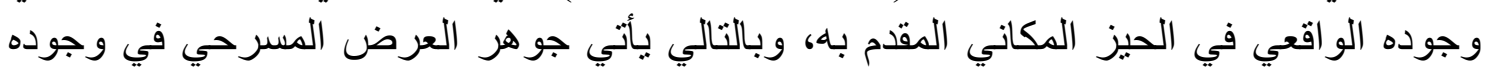

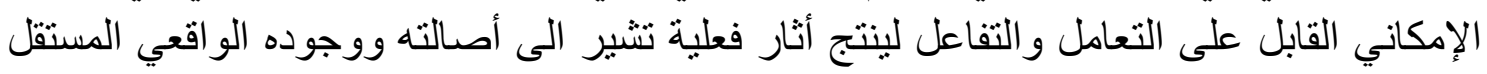
عن الماهية ـ ولتوضيح ما تم تقديمه في الفقرتين (ا، ب) يستعين الباحث بالخطاطة الآتية لتوضيح

جو هر العرض المسرحي ،وفق الثكل رقم (1).

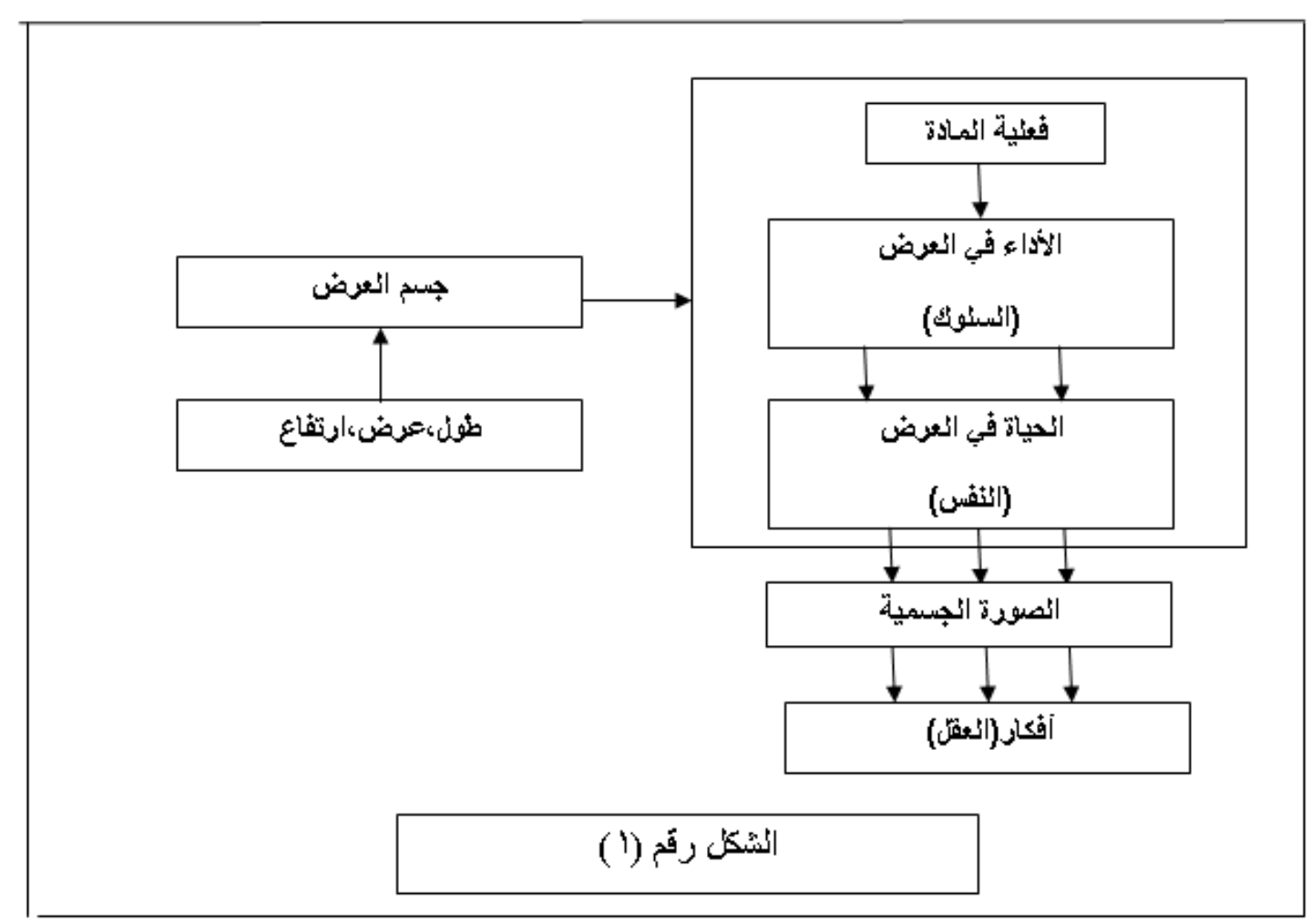


2. عَضَ الوجود الخارجي للعرض:-

ان نظرية (أصالة الوجود) تنظر الى (العَرَض)و هو القسم الثاني للوجود الإمكاني هو الذور الذي يكون

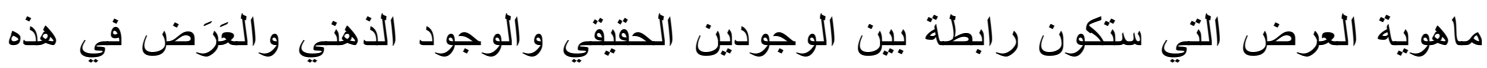
النظرية يتكون من تسعة مقو لات وهي:-

أـ الكم : ويقع في قسمين : الكم المتصل وهو ما يمكن ان يفرض فيه أجزاء بينهما حد مشترك، الكمل. والكم المنفصل ،هو عكس الكم المتصل.

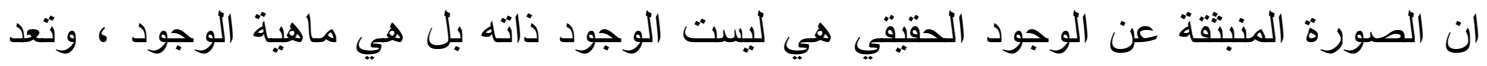

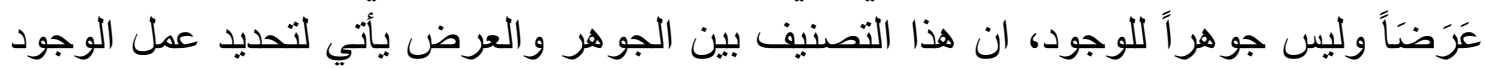

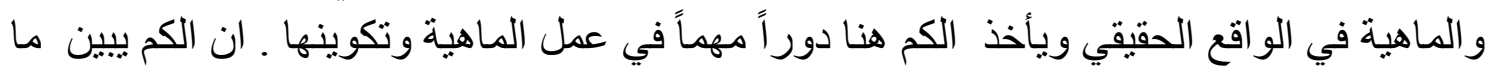

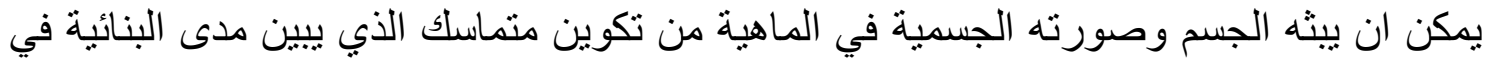

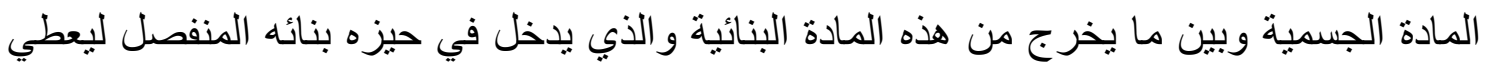

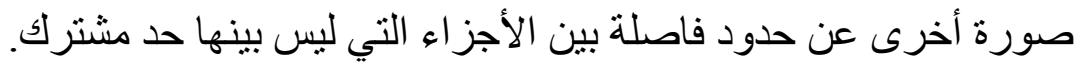

ان للكم ثلاثة صور يظهر بها وهي الخط والسطح والجسم وهو المتصل ،أما المنفصل فهو الذي في

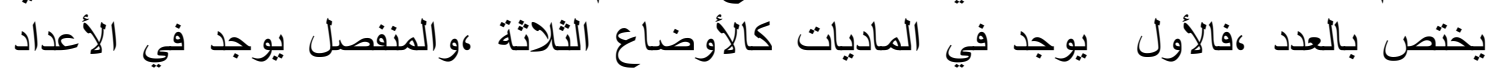

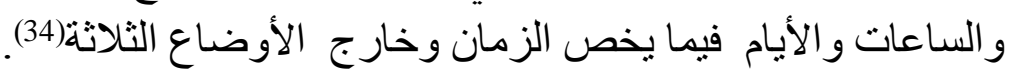

ان مفردات الكم بشقيه المتصل و المنفصل توجد في نظرية العرض المسرحي لـ(هلتون) وفي البناء

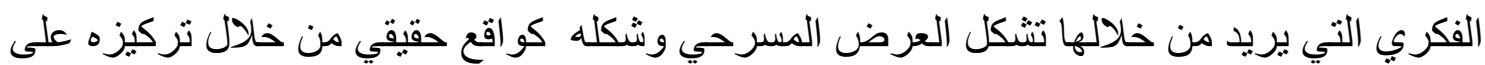

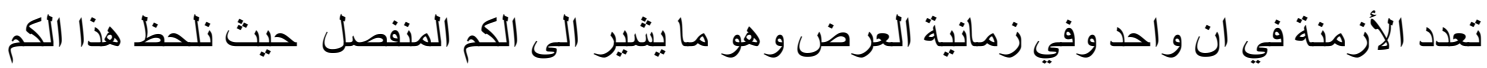

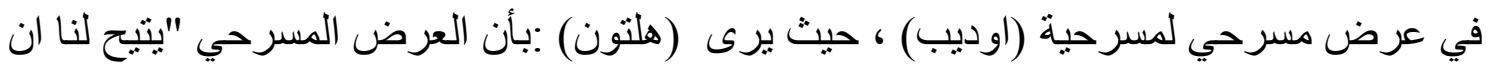

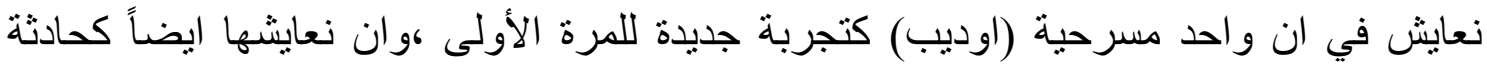

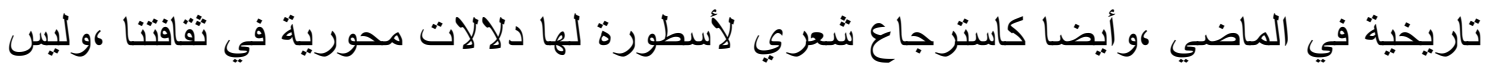

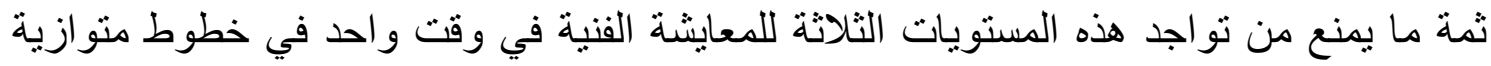
فليس هناك قانون معرفي أو سيكولوجي يحول بيننا وبين التو اجد على مستوي الو الوعي في نظامين 
زمنيين مختلفين أو أكثر في نفس الوقت"(35)،وهذا التعدد في الأزمنة يمكن ان نقارنه بالكم

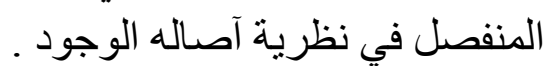

أما الكم المتصل فيظهر في نظرية العرض المسرحي من خلال رؤيته وخصوصاً في تنظيم المكان

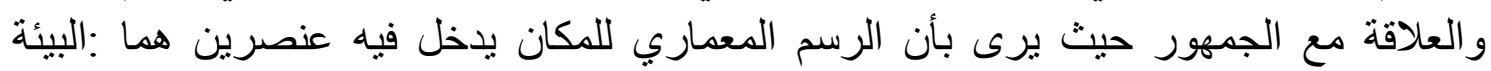

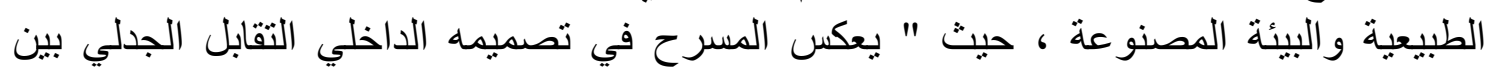
التشكيل الإنساني للمساحة الذي يتميز بخطوطه المستقيمة وبين الإشكال الطبيعية التي تميل اللى في في الاستدارة و الخطوط المنحنية (...) وتفرض جدلية الخطوط المستقيمة و المنحنية نفسها على الإنسان عادة حيث يحاول ان يحدد موقعه في المكان عامة" (36).

هذا فيما يخص المكان أو الحيز المكاني للعرض المسرحي أما فيما يخص الكم المتصل الذي يمكن ان نلاحظه في نظرية العرض عند هلتون وذللك من خلال الديكور (أو المنظر المسرحي) و علاقته

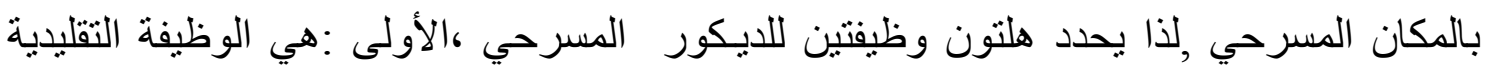
و الثانية الدر امية التي تحديد مو اقع الإحداث ،وكلا الوظيفتين تستخدم الخطوط و السطوح و والأجسام سواء كان في علاقة المكان بالعرض أو في علاقته بالجمهور ،فيقول:" تكتفي هذه الوسائل المحايدة

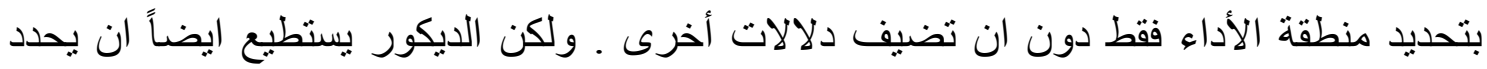

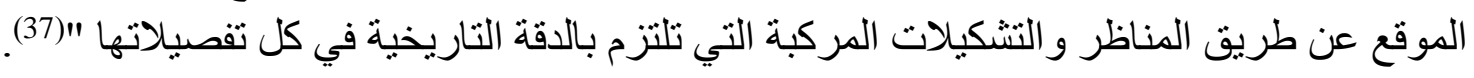
ب ـ الكيف :- ويقسم في نظرية أصالة الوجود الى:-

الكيفيات النفسانية :مثال ذلك (العلم، الإر ادة، الجبن، الثجاعة و غير ها)'و هذه كلها ترتبط

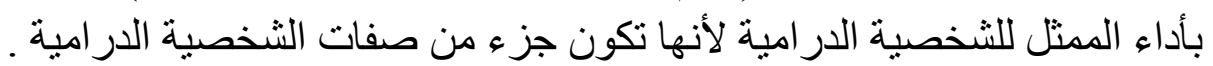

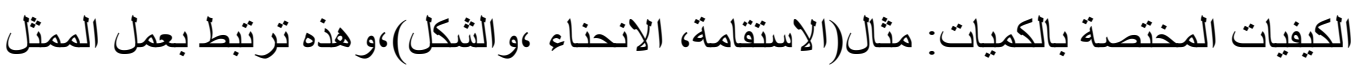
وعمل الديكور ايضاً. الكيفيات الاستعدادية : مثال (الانفعال و اللين ) و هي مرتبطة بأداء الممثل.

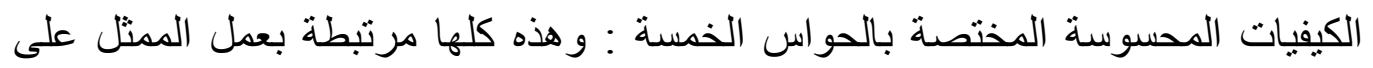
جسده وصوته . 
يستثر (هلتون) في نظريته هذه الكيفيات الأربعة في عمل الممثل وهما اللعب و التدريب وفق دها

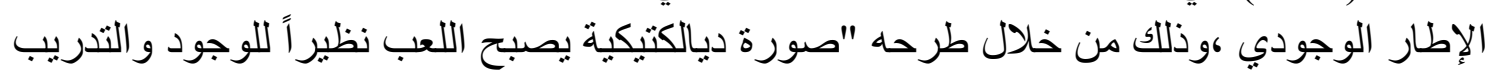

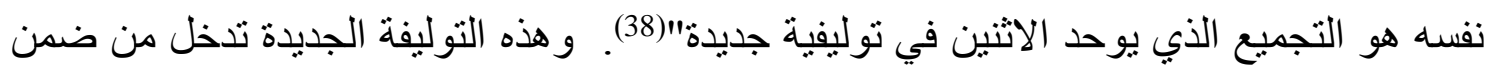

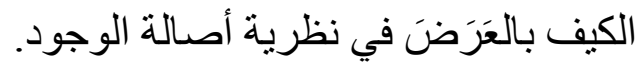

ج - الهيئات الأخرى المتصلة بالأعراض في نظرية الوجود:-

وهي :(اين) المرتبطة بالمكانوكذلك بنسبة وجود الثيء الى المكان، وهي تأتي لتحديد

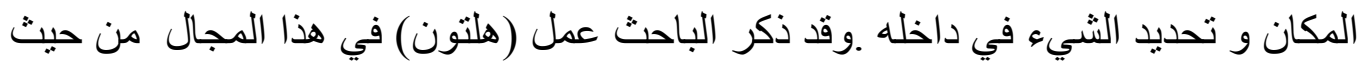

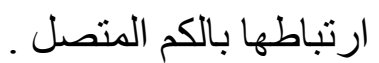

أما هيئة الزمان والمرتبطة بـ(متى) في أصالة الوجود والتي ترتبط بالكم المنفصل ـ حيث

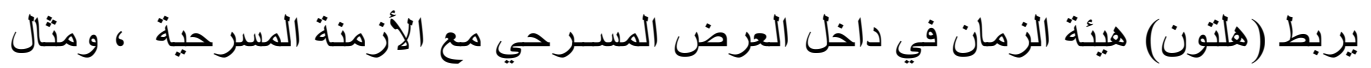

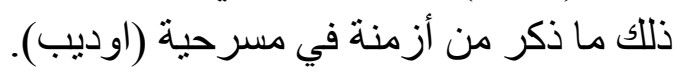

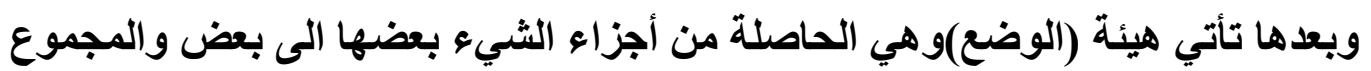

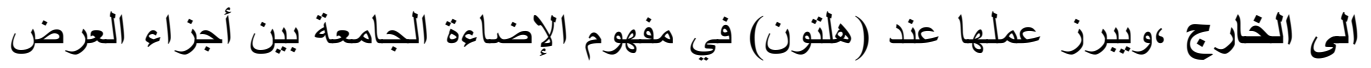

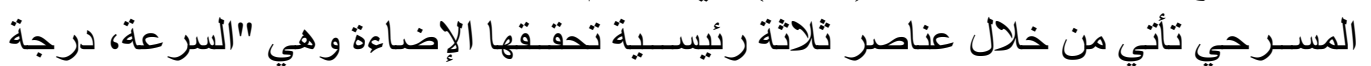

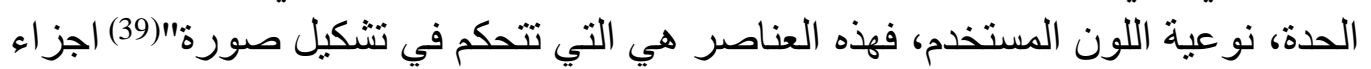
العرض في الحيز المكاني .

وتأتي بعد ذلك هيئة (الجدة) أو الملك أو ما تسمى في نظرية أصالة الوجود (إحاطة

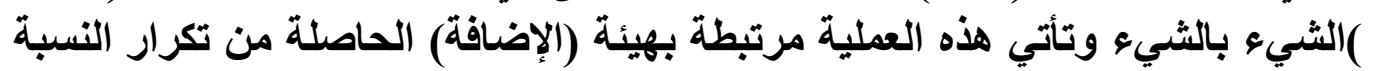

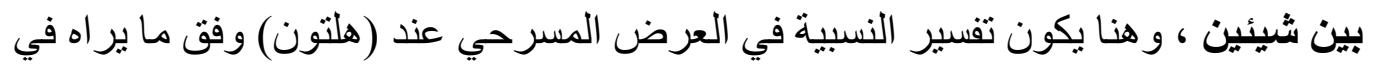
تحقيق العلاقة النسبية مع الو اقع من خلال الثكل الذي يربطئينها للتركيز و التكثيف و النظرة

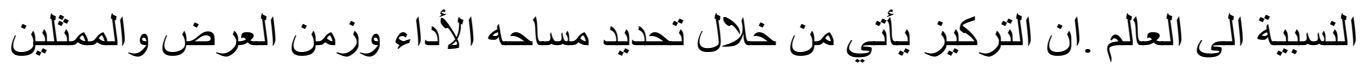

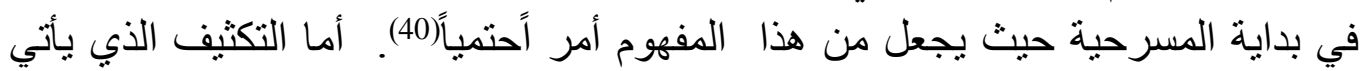

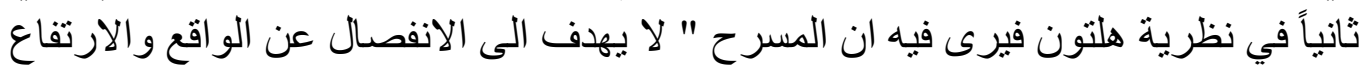

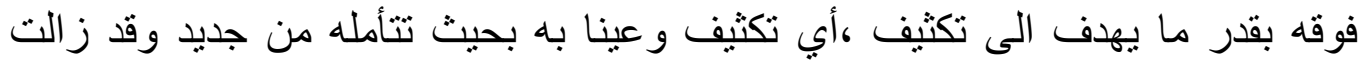

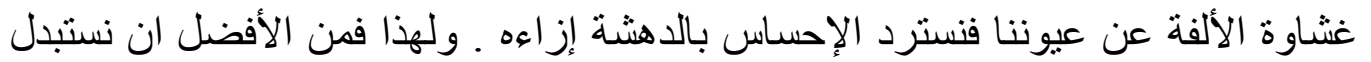

38 بركات ، عفت :نظرية العرض المسرحي عند جوليان هلتون /انترنيت: ملتقى الأدباء والمبدعين العرب/في 2009/2/14، دخول

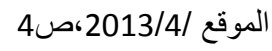

39 هلتون، المصدر السابق ، ص156

40 ينظر : نفسه ،ص293-294 
كلمة الانتشاء بكلمة التكثيف في نظريتنا الدر امية / المسرحية الجديدة ، فالعرض المسرحي

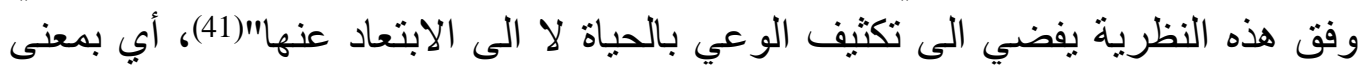

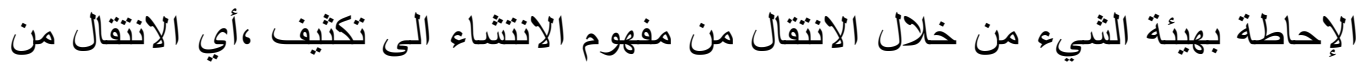

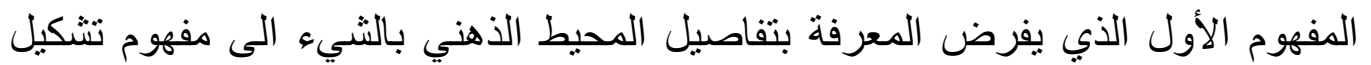

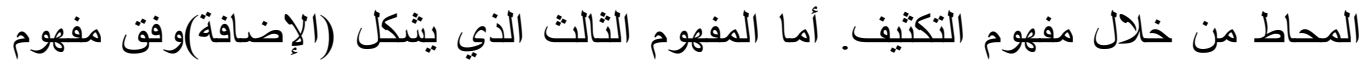
النسبية ،فأن المسرح عند (هلتون) يجب ان يهدف " الى تعميق وعي المتفرج بهذا العالم

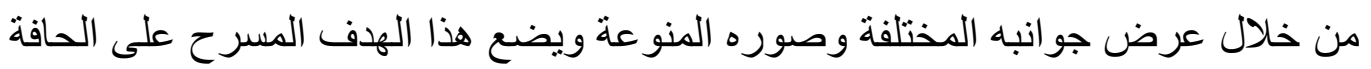
القصوى على دائرة الوعي الثقافي السائد في موقع القيادة الطليعية ويجعل منه وسيطاً ثقاقياً"(42)

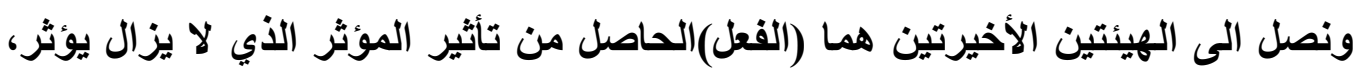

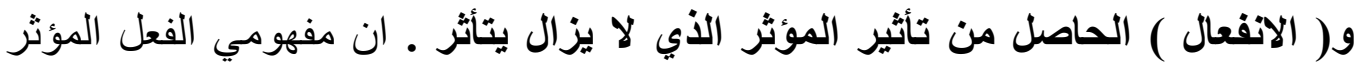

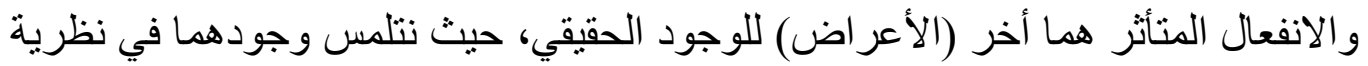
العرض المسرحي عند (هلتون) من خلال الفاعلية في العرض كمؤثر يقع في داخله

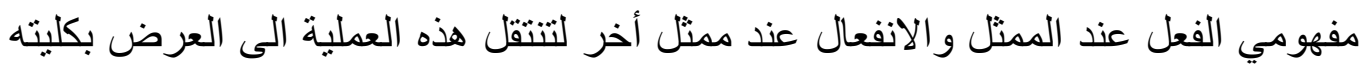

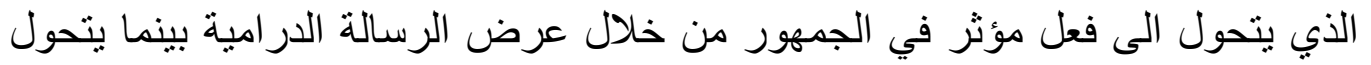
الجمهور الى خانة المتأتزر الذي يتأثر بفعل العرض التئ المسرحي. ان طرفي المعادلة المؤثر و المتأثر و التي تحدث في داخل العرض خانة وخارجه يرى التئ فيها (هلتون) عملية انتقال طبيعية من الممثل كمؤثر ومؤثر الى المتفرج حيث يقول: "ان الممثل حين بنجح في أداء مهمته

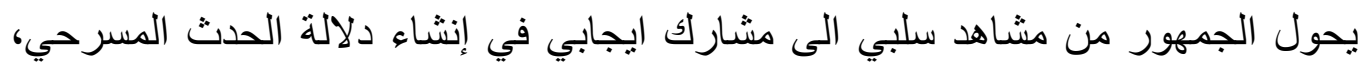

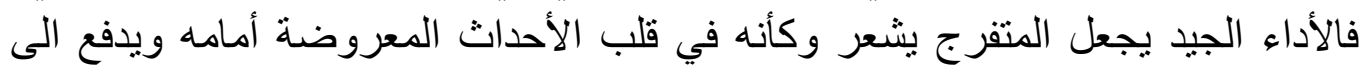

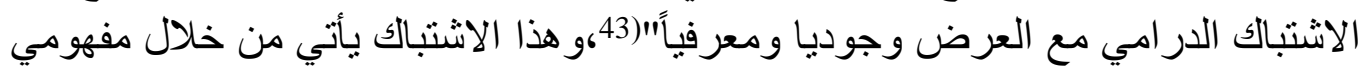
الفعل و الانفعال .

ولتوضيح ما تم تقديمه في الفقرات(ا، ب، ج) يضع الباحث الخطاطة الآتية لتوضيح (العرض) في أصالة الوجود و ارتباطه في نظرية (هلتون) المسرحية وفق الثكلين رقم (2) ورقم (3) (2). 


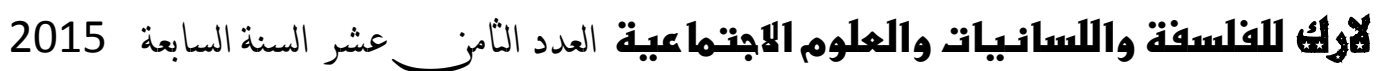

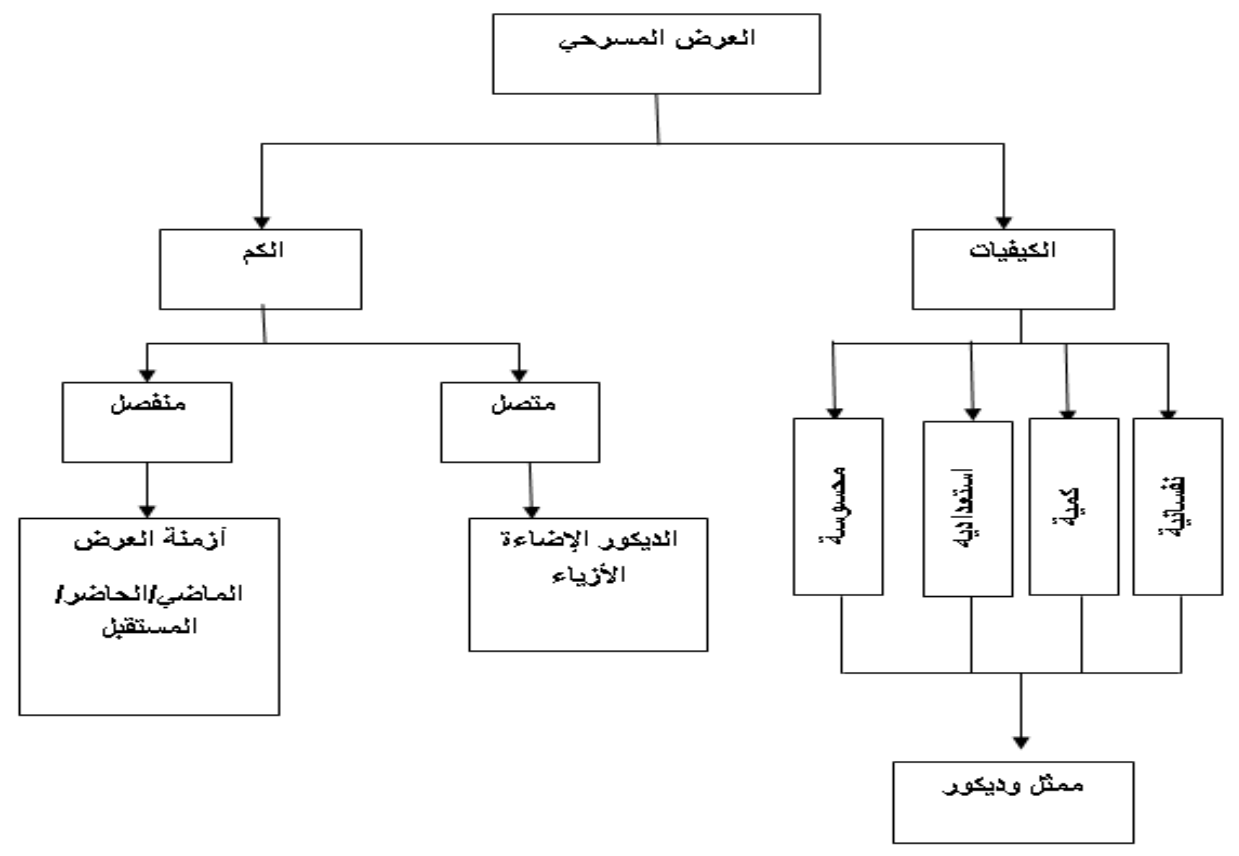

(r) شكن رقم (r) (1)

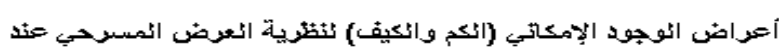
جوئياث هنتون 


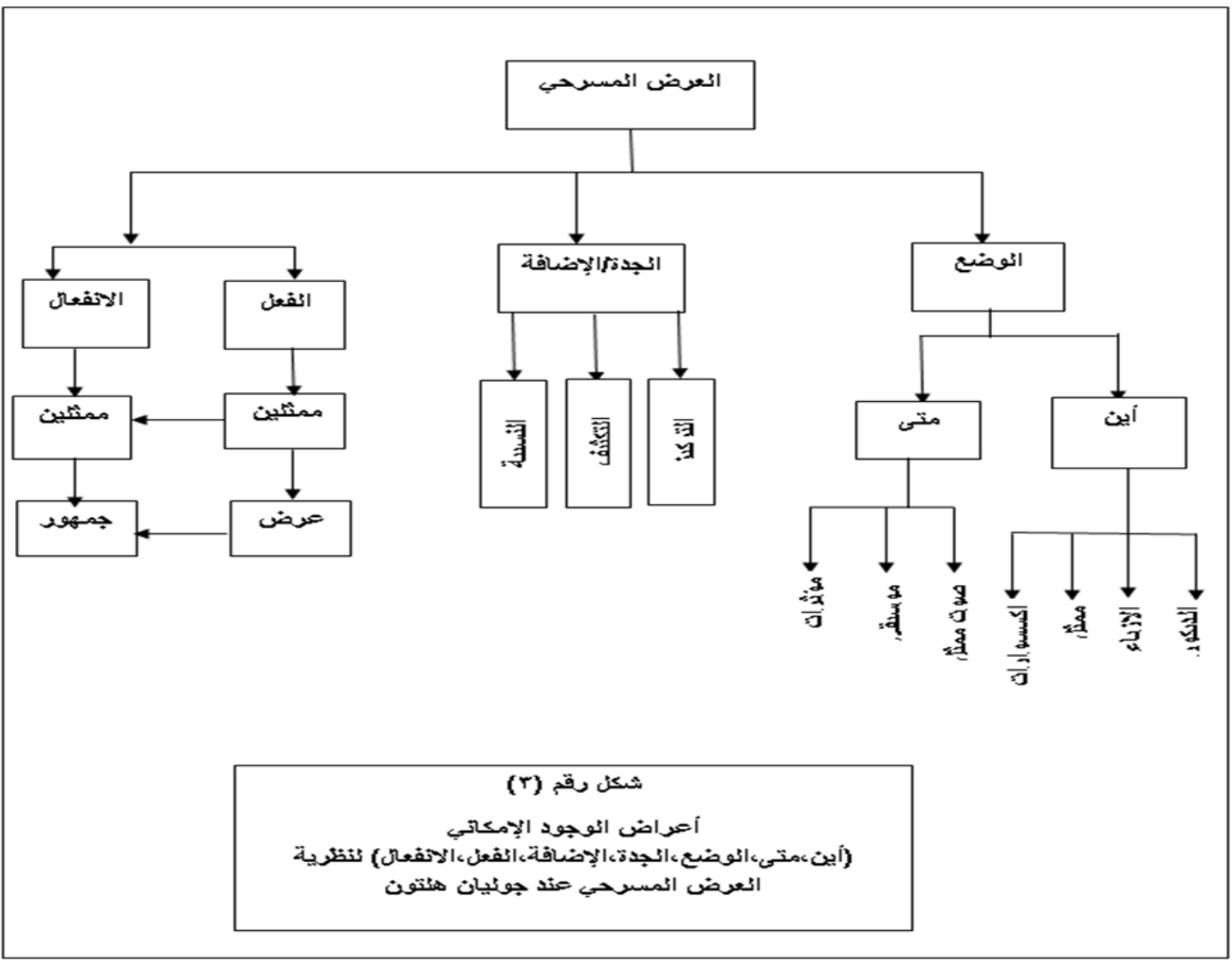

ثانياً الوجود المسرحي الخارجي /الماهية الرابطة/الوجود الأهي عند الجمهور:-

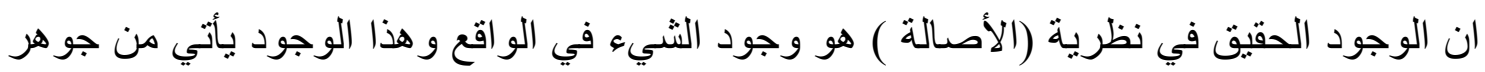

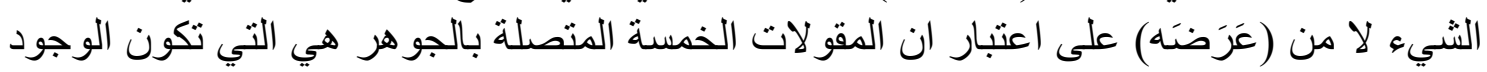

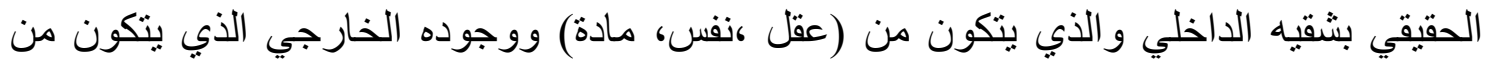

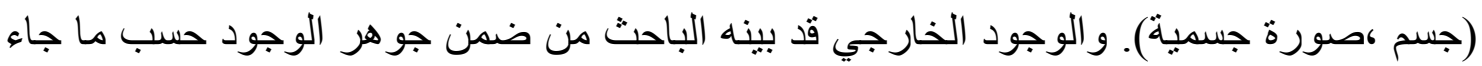

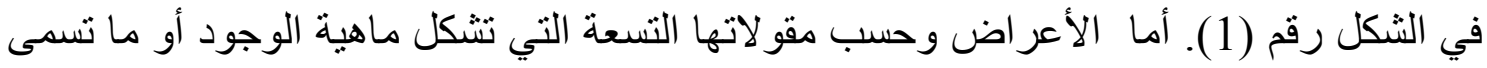
بالماهية الر ابطة فهي كذلك قد تم شرحها وتوضيحها وفق الثكلين رقم (2) و(3).وألان يتطرق الباحث الى الوجود الذهني الذي يتشكل في ذهنية المتلقي من ماهية الوجود الحقيقي وبالتالي تتكون ماهية ذهنية في داخل الوجود الذهني للشيء المشاهد ، ولتوضيح هذه الخطوات وكيفية تكوين

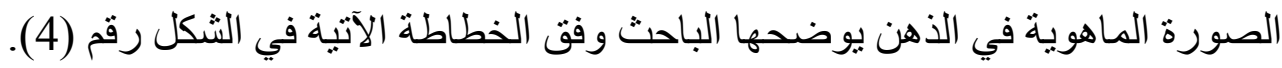




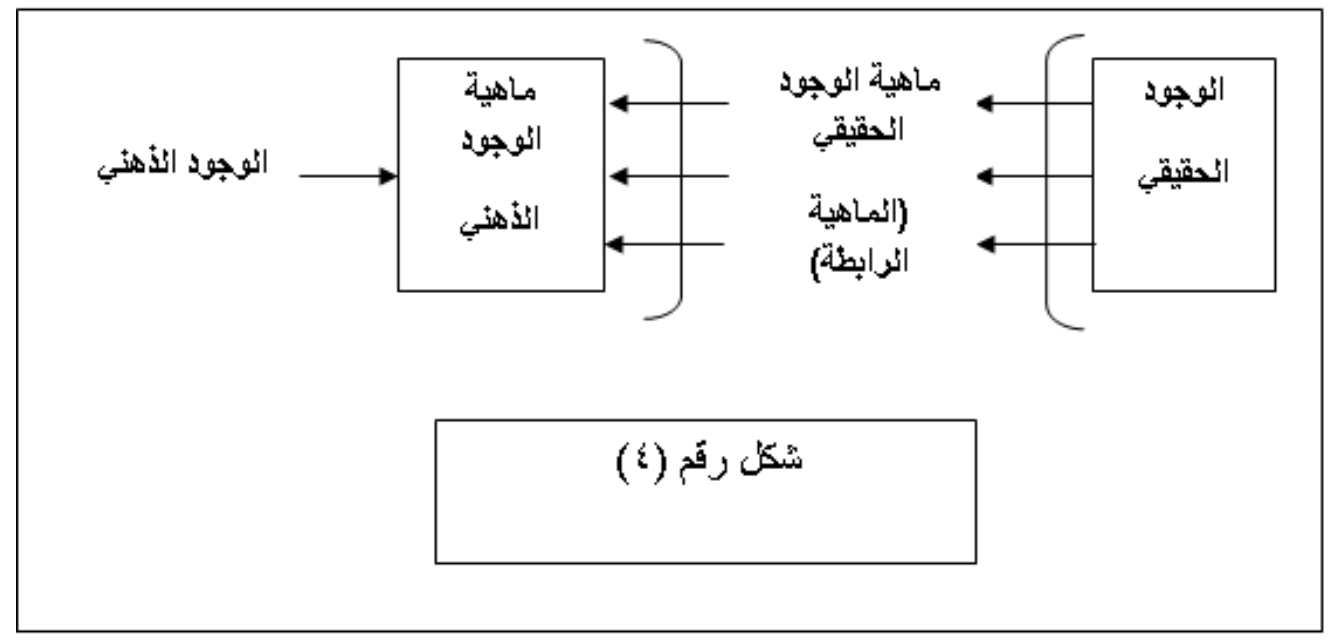

ان الوجود الحقيقي للعرض المسرحي و الذي يتمثل في جو هره يعطي من خلال جسمه و الصورة

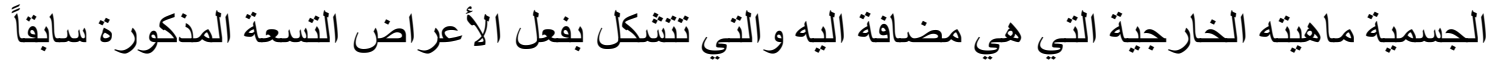

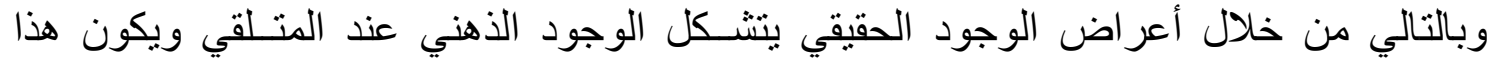
الوجود الذهني بماهيته الذهـنية هو اعتباري وليس حقيقي ،لان الحقيقة الموجودة هي فيما يخص لئس

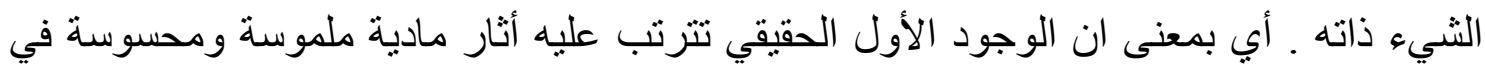

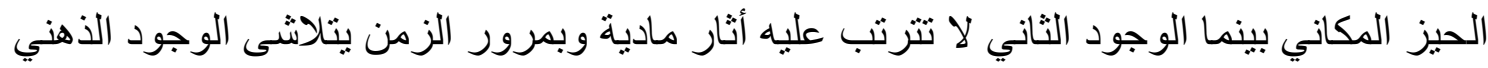
وماهيته من ذهن المتلقي إذا ما تمت عمليات الجد والإضافة وتكرار العملية في عرض الته الأحداث

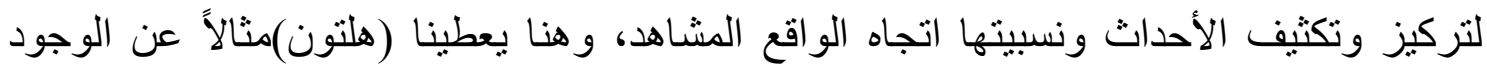

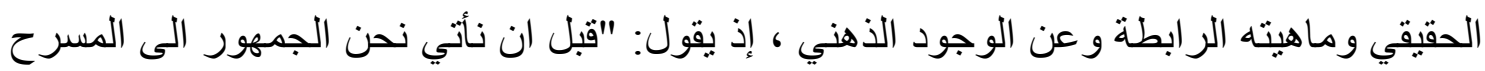

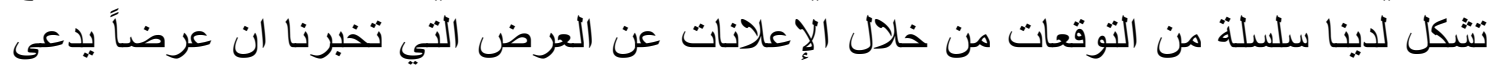

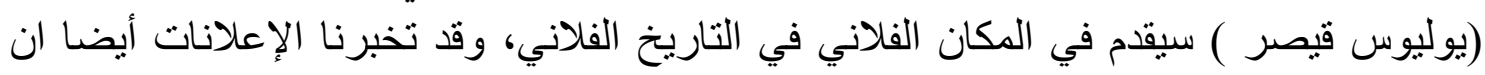

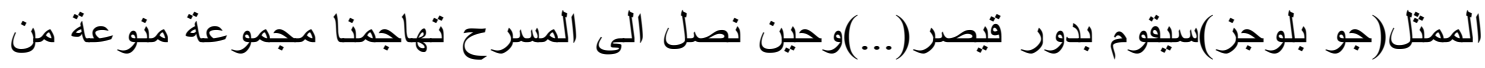

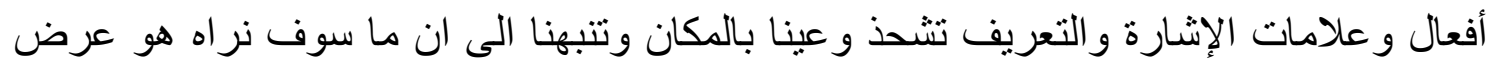

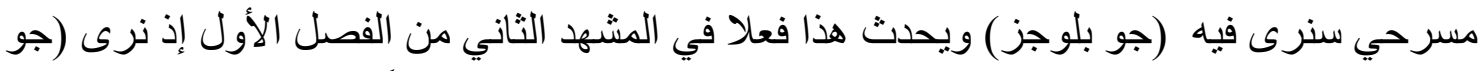

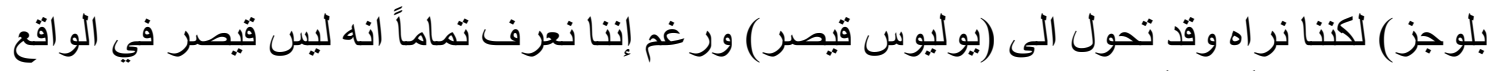

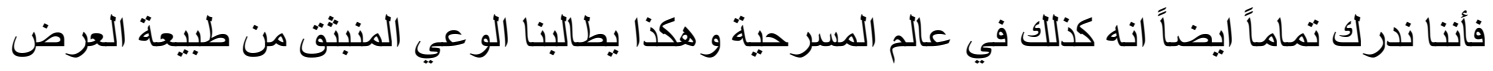
المسرحي بأن نصدق حقيقتين متناقضتين عن وجودهما انه (قيصر ) و انه ليس (قيصر )"(44). 
ان نشكيل الوجود الذهني بماهيته عن مسرحية (يوليوس قيصر )بشخصية (قيصر) المسرحية وشخصية (جو) الممثل الحقيقي هاتين الحقيقتين المتناقضتين التين يشاهدهما الجمهور ويعيهما تجعل من وجود العرض المسرحي هو المصداق الحقيقي لما يراه الجمهور وليس شخصيتينين

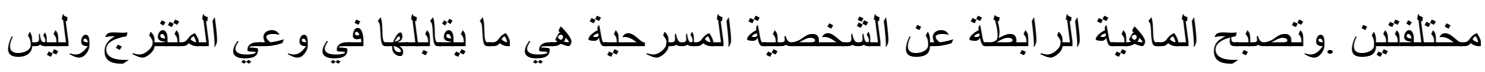
الثخصيتين المتناقضتين وبالتالي يتشكل الوجود الذهني بماهيته من الوجود الحقيقي للعرض إهي المسرحي وليس من شيء أخر .

و ون اجل توضيح فكرة (جوليان هلتون) في المثال السابق نوضحه بالخطاطة الآتية في الشكل

رقم)(5).

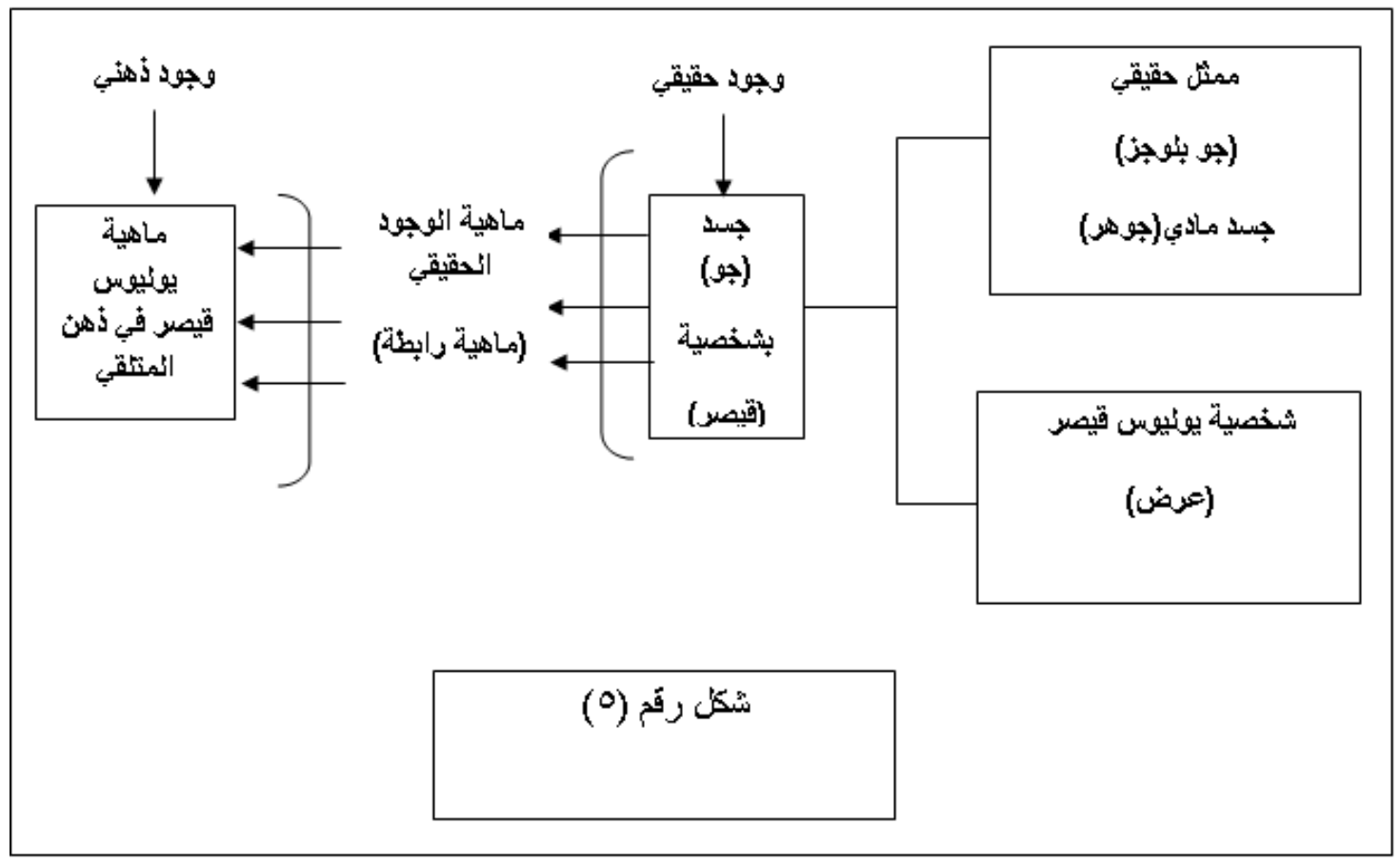

ثالثاً الموضوع(خطاب العرض المسرحي)/الحمل/المحمول.

ان نظرية الوجود تنظر الى الحمل على أساس ارتباطه بالموضوع فأما ان بكون الحمل ذاتي ويأتي

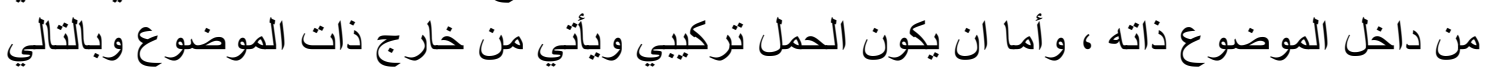

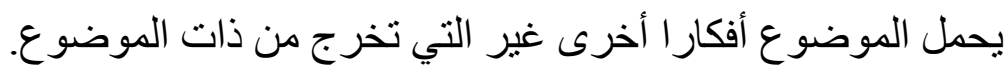
ان هذه المفاهيم فيما يخص الحمل الذاتي و التركيبي، يمكن ان نجدها في وجهه نظر (هلتون)اتجاه عملية التلقي للعرض المسرحي من خلال الاشتباك الدر امي بين العرض المسرحي و الجمهور وهذا الاشتبالك يقع في مستوبين: 
1.مستوى انثتباك يقع على خشبة المسرح الذي يشكل حبكة المسرحية وهنا يدخل الحمل الذاتي المأخوذ من ذات الموضوع (موضوع العرض المسرحي) لإنتاج محمول من ذات الموضوع. 2.مستوى اشتباك مع الجمهور يقع في الوجود الذهني عن فعل إبداعي في ذهن المتلقي لإنتاج

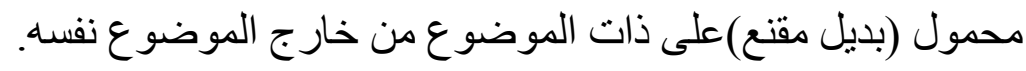

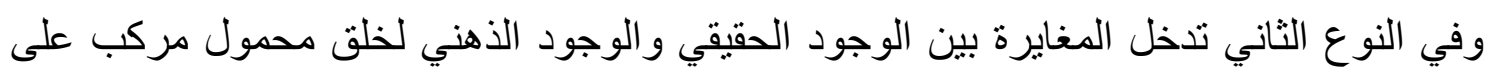

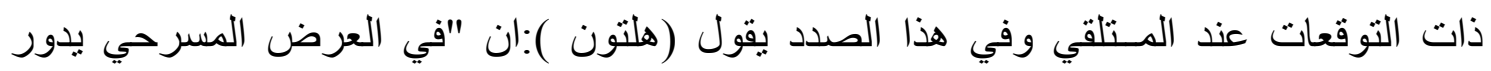

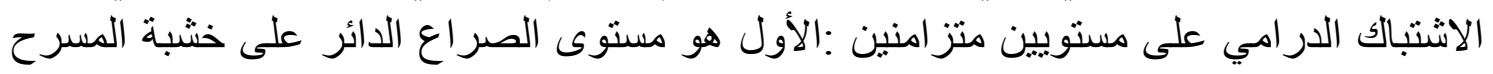

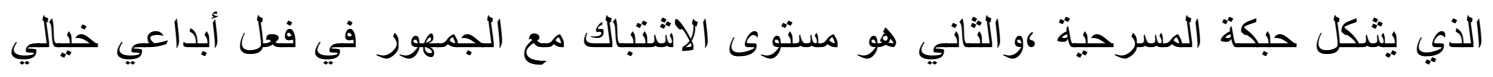

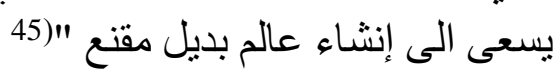
و هنا يظهر وجود تقسيم للتلقي عند (الجمهور المسرحي) الى مستويين وفق نظرية (هلتون) هما:1) مستوى مباشر:- وهو الذي يقع مع الأحداث المقدمة على خثبة المسرح وهنا يرتبط مستوى

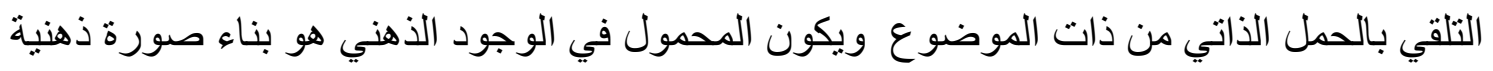

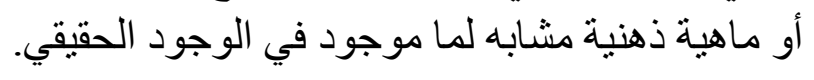

2) مستوي غير مباشر :- وهو ما يقع فيه تلاقي أفاق التوقعات عند المتلقي مع أفاق الفعل الإبداعي

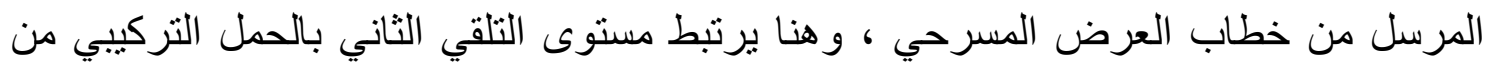

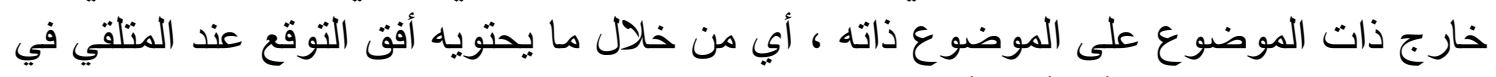

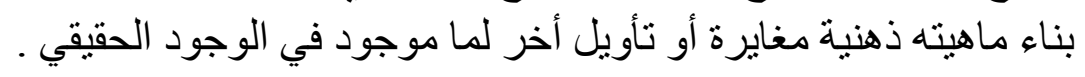

و هنا تدخل مستويات الإدراك عند المتلقي في الحمل الذاتي (من خلال المدرك الحسي) أو في الحمل التركيبي (من خلال المدرك المبني على الخيال او الوهم) في تبني فكرة تأويلية محددة عن الأن الموضوع.

رابعاً_ مراتب الوجود في العرض المسرحي(ألكتب/اللفظي/الذهني) :-

ترتب نظرية (أصالة الوجود) ،الوجود الى ثلاثة مر اتب ، أي ان الوجود يمر في ثناثة در اتب هي:

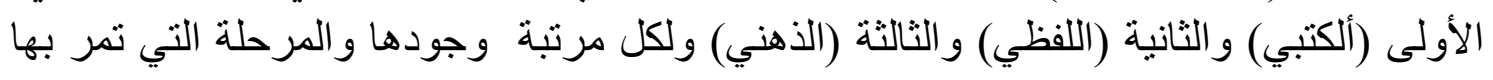




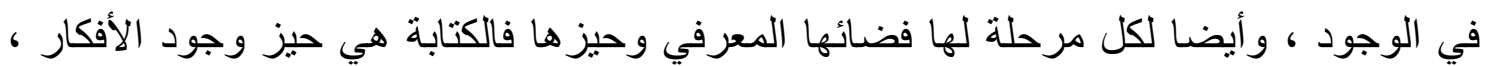

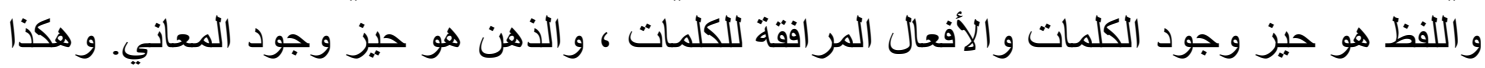
فأن العملية تكرر في مر اتب الوجود الثناثة .

ان مراتب الوجود الثلاثة موجودة في العملية المسرحية بصورة عامة ولكن عند (هلتون) لها

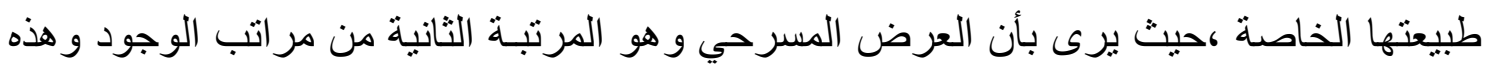

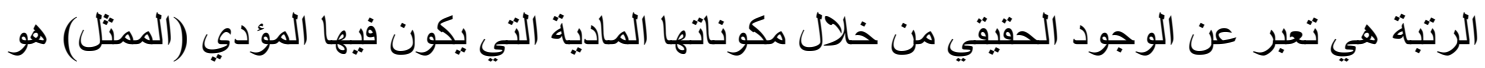

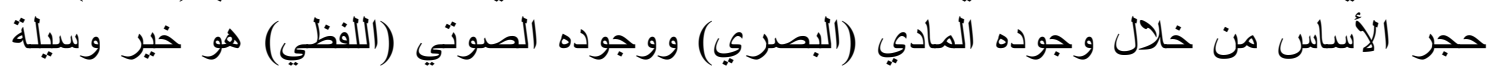

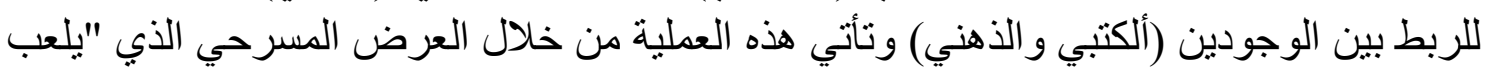

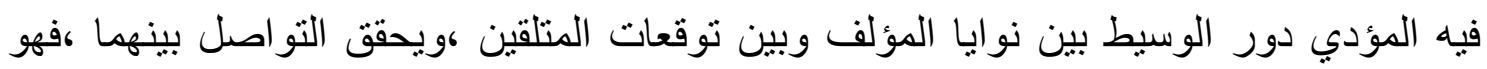
ينوب عن المؤلف المسرحي أمام الجمهور وينوب عن الجمهور أمام المؤلف المسرحي ـوقد يقول ئون

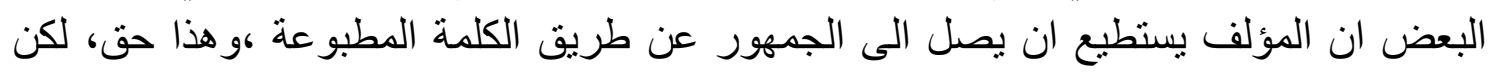

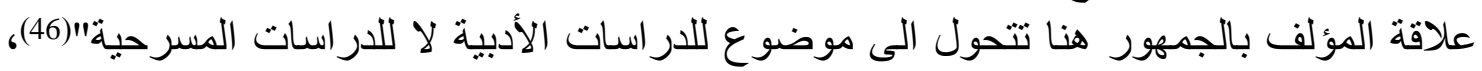
وبالتالي فأن العرض المسرحي هو المرتبة الثانية التي تحقق تواصل بين الوجودين الكتبي و الذهني, وهنا يضع الباحث الخطاطة الآتية لتوضيح مراتب الوجود التية الثلاثنة في نظرية العرض المسرحي لـ(جوليان هلتون) وفق الشكل رقم (6). 


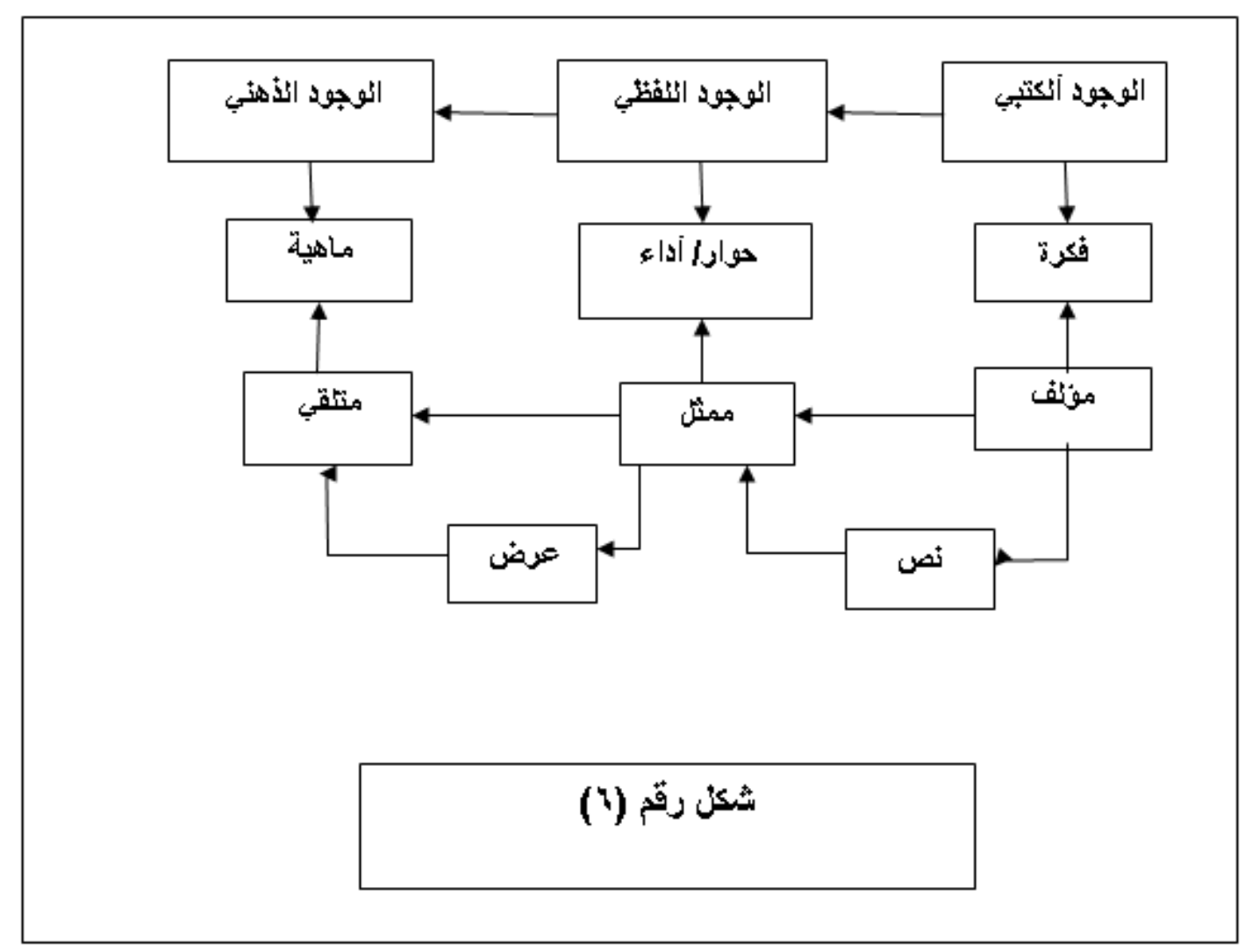

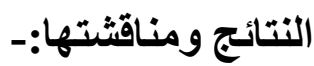

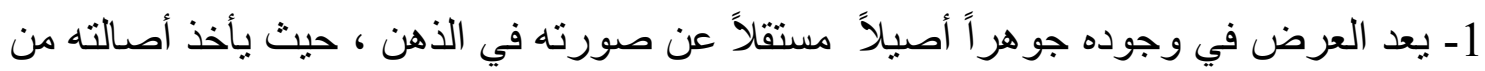

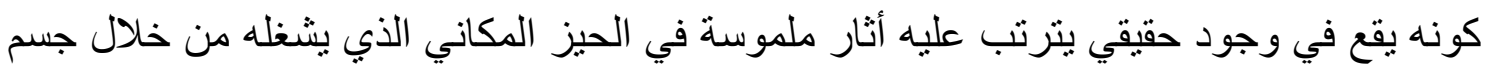

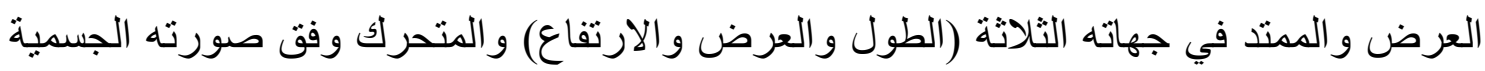
و امتداداتها العقلية و النفسية و المادية .

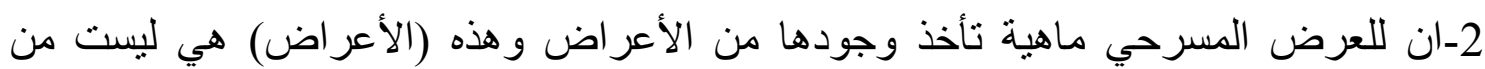

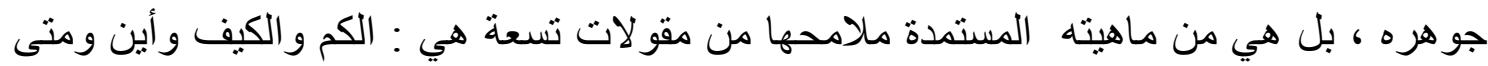

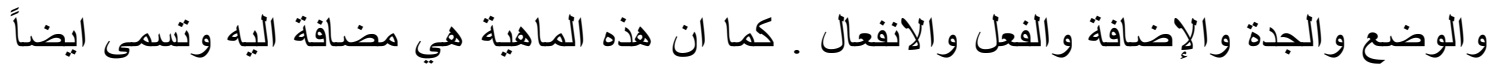

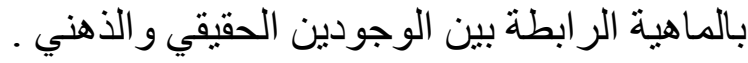

3- يتشكل العرض المسرحي أنطولوجيا من ثلاثة مراتب ، أذ يمر في ثلاثة مر احل تنتج وجوده

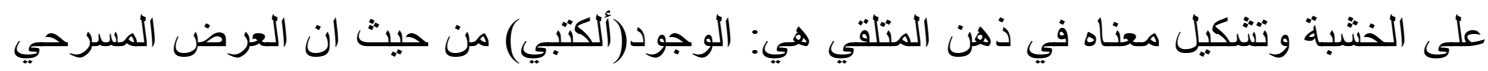
هو كتابة كنص مسرحي وأيضاً كتابة على خثبة المسرح التي يرافقها ويتماش معها الوجود 


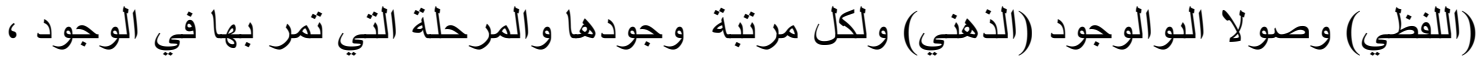

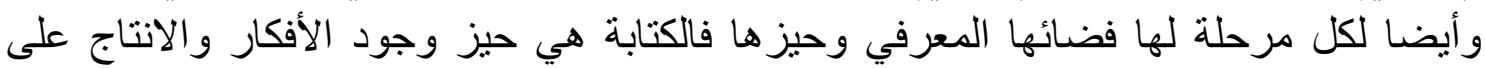

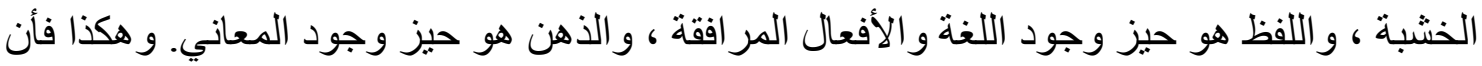
العملية تكرر في مر اتب الوجود الثلاثة . وهئة

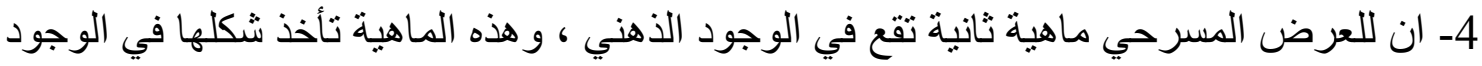

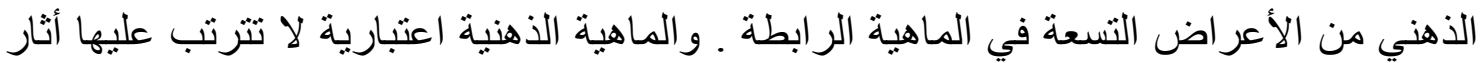
فعلية وجودية حقيقية في داخل الذهن ، بل تبقى صورة ذهنية ، تفقد ملامحها تدريجيا إذا لم تتكرر

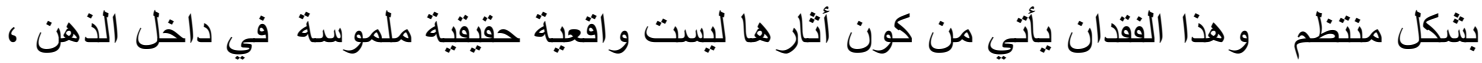

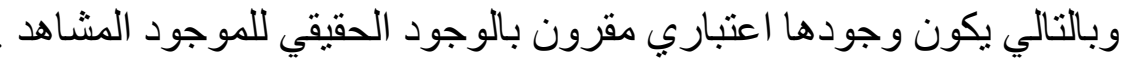

5- تتكون الماهية الذهنية نتيجة حملين الأول ذاتي وهو يحمل من ذات الموضوع ويعمل على

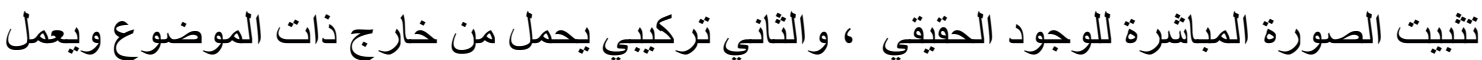
على إضافة معلومات أخرى تكمل النقص الحاصل في معنى الصورة الذهنية ، وبالتالي فأن إكمال

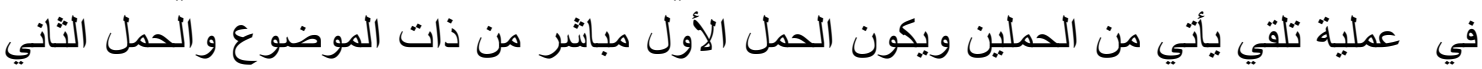

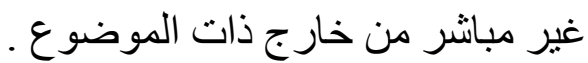

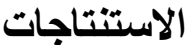

يستتج الباحث ان أنطولوجيا العرض المسرحي هي من الاسس المهمة في در اسة المسرح والية

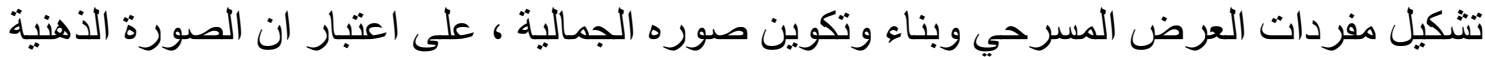

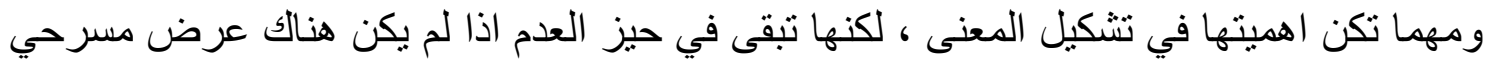
متشكل فعليا في الفضاء المسرحي كوجود متحقق على ارض الوض الو اقع معرفياً وجمالياً

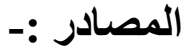

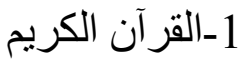

2- إبر اهيم ، زكريا: در اسات في الفلسفة المعاصرة ، القاهرة : مكتبة مصر ،1987 3- أحمد ، إبر اهيم : انطولوجيا اللغة عند مارتن هيدجر ، بيروت : الدار العربية للعلوم ناشرون

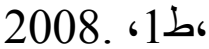

4- آرون، بول ، دينيس سان- جاك ، آلان فيالا : معجم المصطلحات الأدبية ، ترجمة: د محمد

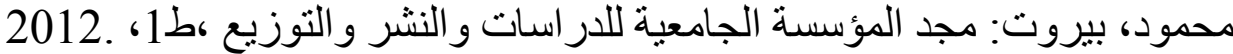


5- أيغلتن ، تيري : مقدمة في النظرية الأدبية ، ترجمة د ـ ـ عاصم إسماعيل الياس ،بغداد : دار

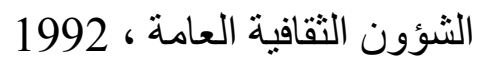

6- بركات ،عفت :نظرية العرض المسرحي عند جوليان هلتون ،انترنيت: ملتقى الأدباء والمبدعين

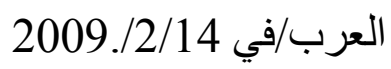

7- التميمي ، قيصر : الفلسفة ، قم : دار الفر اقد للطباعة و النشر ،ج2، ط1، 2010 8- جديدي، محمد : الفلسفة الإغريقية ، بيروت : الدار العربية للعلوم ناثرون،ط1، 2009 . 9- ألحفني ، عبد المنعم : المعجم الثامل لمصطلحات الفلسفة ، القاهرة : مكتبة مدبولي 3،2000.b،

10- دغيم ، سميح : موسوعة مصطلحات صدر الدين الثيرازي ،ج2، قم: مؤسسة ذوي القربى ،

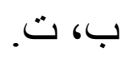
11- رايت: وليم كلي: تاريخ الفلسفة الحديثة، نرجمة: محمود سيد احمد، بيروت: التنوير للطباعة

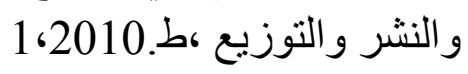

12- رزونتال .م ، ي ـ يودين : الموسوعة الفلسفية ، ترجمة: سمير كرم ، بيروت: دار الطليعة

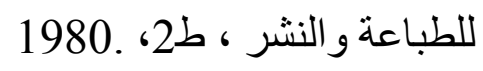

13- الرفاعي ، عبد الجبار : في أصالة الوجود و اعتبارية الماهية / انترنيت : موقع موسو عة دهشة . 2012/12/15 ،

14- الثبيرازي ، صدر الدين محمد : الحكمة المتعالية ، بيروت: دار إحياء التراث العربي >1-

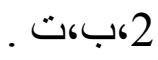

15- الثريف ، محمد بن عبد الغفار: العارف بالله الإمام جلال الدين الرومي وكتابه المثنوي،

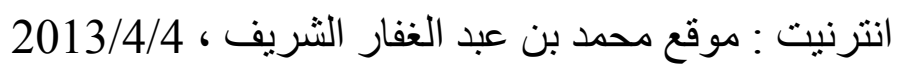

16- عينات ،عبد الكريم :نيتشه والإغريق ،إثكالية اصل الفلسفة ، بيروت : الدار العربية للعلوم

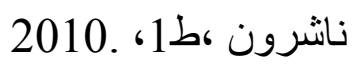

17- القرني ، عبد الحفيظ فر غلي علي : الثيخ الأكبر ، محيى الدين بن عربي ، القاهرة : الهيئة المصرية العامة للكتاب، .1986 لعبد 
18- كوربان، هنري :مقدمات لمؤلفات شهاب الدين السهروردي الفلسفية والصوفية ، ترجمة : فريد الز اهي ، بيروت : مؤلفات الجمل ، 2012 19- محمد حسين : بداية الحكمة ، بغداد : مكتبة الكلمة الطيبة ،ط1، 2012. مفرج، جمال : الإرادة والتأويل ، تغلغل النينشوية في الفكر العربي كبيروت : الدار العربية للعلوم

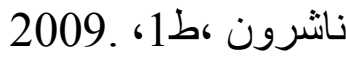

20- المنجد في اللغة و الأعلام، طبعة التاسعة والثلاثون ، بيروت : دار المشرق ، 2002 21- هاني، إدريس : ما بعد الر اثدية ، بيروت: مؤسسة دائرة معارف الفقه الاسلامي ، .2000 22- هلتون, جوليان: نظرية العرض المسرحي ,ترجمة نهاد حليمة ,القاهرة: هلا للنشر والتوزيع , 2000. 